\title{
Uptake of dissolved inorganic and organic nitrogen by the benthic toxic dinoflagellate Ostreopsis cf. ovata
}

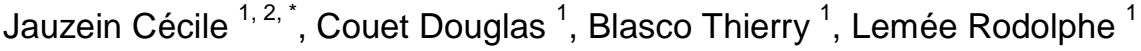 \\ ${ }^{1}$ Sorbonne Universités, UPMC Univ Paris 06, INSU-CNRS, Laboratoire d'Océanographie de \\ Villefranche, Villefranche sur mer, France \\ 2 IFREMER, Centre de Brest, DYNECO PELAGOS, F-29280 Plouzané, France \\ * Corresponding author : Cécile Jauzein, email address : cecile.jauzein@ifremer.fr
}

\begin{abstract}
:
Environmental factors that shape dynamics of benthic toxic blooms are largely unknown. In particular, for the toxic dinoflagellate Ostreopsis cf. ovata, the importance of the availability of nutrients and the contribution of the inorganic and organic pools to growth need to be quantified in marine coastal environments. The present study aimed at characterizing N-uptake of dissolved inorganic and organic sources by $O$. cf. ovata cells, using the ${ }^{15} \mathrm{~N}$-labelling technique. Experiments were conducted taking into account potential interactions between nutrient uptake systems as well as variations with the diel cycle. Uptake abilities of $\mathrm{O}$. cf. ovata were parameterized for ammonium $\left(\mathrm{NH}_{4}{ }^{+}\right)$, nitrate $\left(\mathrm{NO}_{3}{ }^{-}\right)$and $\mathrm{N}$-urea, from the estimation of kinetic and inhibition parameters. In the range of 0 to $10 \mu \mathrm{mol} \mathrm{N} \mathrm{L}^{-1}$, kinetic curves showed a clear preference pattern following the ranking $\mathrm{NH}_{4}{ }^{+}>\mathrm{NO}_{3}{ }^{-}>\mathrm{N}$-urea, where the preferential uptake of $\mathrm{NH}_{4}{ }^{+}$relative to $\mathrm{NO}_{3}{ }^{-}$was accentuated by an inhibitory effect of $\mathrm{NH}_{4}{ }^{+}$ concentration on $\mathrm{NO}_{3}{ }^{-}$uptake capabilities. Conversely, under high nutrient concentrations, the preference for $\mathrm{NH}_{4}{ }^{+}$relative to $\mathrm{NO}_{3}{ }^{-}$was largely reduced, probably because of the existence of a lowaffinity high capacity inducible $\mathrm{NO}_{3}{ }^{-}$uptake system. Ability to take up nutrients in darkness could not be defined as a competitive advantage for $O$. cf. ovata. Species competitiveness can also be defined from nutrient uptake kinetic parameters. A strong affinity for $\mathrm{NH}_{4}{ }^{+}$was observed for $\mathrm{O}$. cf. ovata cells that may partly explain the success of this toxic species during the summer season in the Bay of Villefranche-sur-mer (France).
\end{abstract}

\section{Abbreviations}

- $\quad$ EA - IRMS, Elemental Analysis - Isotope Ratio Mass Spectrometry;

- PC, particulate carbon;

- $\mathrm{PN}$, particulate nitrogen

Keywords : Uptake, Nitrogen, Dinoflagellate, Ostreopsis, Kinetics, Interactions 


\section{Introduction}

Benthic harmful algal blooms represent an increasing threat to human and environmental health worldwide (Parsons et al., 2012; Rhodes, 2011). Toxic dinoflagellates belonging to the genus Ostreopsis Schmidt are common components of tropical epibenthic microalgae communities and have also been reported in several temperate waters, including coastal waters of the Mediterranean Sea (Vila et al., 2001), New Zealand (Rhodes et al., 2000) or Japan (Taniyama et al., 2003). Along the Mediterranean coasts, massive Ostreopsis cf. ovata blooms regularly occurred during the summer season and early fall (e.g. Aligizaki and Nikolaidis, 2006; Mangialajo et al., 2011). Some of them were associated with serious cases of human health disorders (Brescianini et al., 2006; Vila et al., 2016). Symptoms of human illnesses include skin irritations, fever or broncho-constriction, partly due to exposure to toxic marine aerosols (Ciminiello et al., 2014). Blooms of $O$. cf ovata can also have deleterious effects on benthic marine invertebrates (Accoroni et al., 2011; Guidi-Guilvard et al., 2012; Pagliara and Caroppo, 2012; Gorbi et al., 2013). The toxicity of $O$. cf ovata is associated with the presence of palytoxin-like compounds that include putative palytoxin and ovatoxins-a, b, c, d, e and f (Uchida et al., 2013; Brissard et al., 2014), and mascarenotoxins-a and c (Rossi et al., 2010; Scalco et al., 2012). Palytoxin-like compounds have already been found in Mediterranean fauna (Biré et al. 2015) but no related food poisoning has been reported.

The processes that shape dynamics of benthic dinoflagellate populations and facilitate the development of specific toxic species are still poorly understood, mainly because benthic dinoflagellates have received considerably less attention than their planktonic counterparts (Parsons et al. 2012). Among potential controlling factors, temperature may represent a key factor in the seasonality of $O$. cf ovata blooms in temperate areas (Mangialajo et al., 2008; Accoroni et al., 2014; Accoroni and Totti, 2016). The control of bloom dynamics by water temperate has still to be clarified, however, as its appeared to vary with geographical areas 
(Accoroni and Totti, 2016). Concerning other physical parameters, several studies reported higher abundances of $O$. cf ovata in sheltered sites compared to the ones exposed to wave action (e.g. Totti et al., 2010; Selina et al., 2014). This suggests that hydrodynamic conditions can have strong effects on bloom development and maintenance; according to Accoroni and Totti (2016), this influence of hydrodynamics on $O$. cf ovata bloom may be particularly pronounced under high levels of abundance (Accoroni and Totti, 2016).

The growth and maintenance of microalgae populations are also directly dependent on nutritive sources that are fueling the blooms. The regulation of $O$. cf. ovata bloom dynamics by the nutrient resource is largely unknown. Cells of Ostreopsis are expected to be mixotrophic, able to complete their autotrophic growth (based on photosynthesis and uptake of inorganic sources) by the use of organic matter (Burkholder et al., 2008). Among potential organic sources, the phagotrophy of preys by Ostreopsis cells was investigated (Faust et al., 1996; Barone, 2007) but is still a matter of debate (Escalera et al., 2014). The potential use of dissolved organic phosphorus by $O$. cf ovata cells was tested by Pistocchi et al. (2014), when the uptake of dissolved organic nitrogen sources has not been analyzed yet. Concerning the inorganic sources of nutrients, previous studies reported conflicting results regarding relationships between nutrient availability and occurrence of Ostreopsis blooms (Accoroni and Totti, 2016). Several field studies conducted in the NW Mediterranean Sea did not show any relationship between epiphytic $O$. cf. ovata abundances and concentrations of dissolved inorganic nutrients (dissolved inorganic nitrogen, DIN, and phosphate) (Vila et al., 2001; Accoroni et al., 2011). Conversely, Parsons and Preskitt (2007) found that Ostreopsis sp.1 abundance was positively correlated with nutrient concentrations in the waters surrounding Hawai'i. A positive correlation between phosphate concentration and $O$. cf. ovata abundance was also reported by Cohu et al. (2013) in the NW Mediterranean Sea. In the Northern 
Adriatic Sea, phosphate pulses in the bloom onset period may possibly stimulate $O$ cf. ovata growth in these coastal waters (Accoroni et al., 2015).

The importance of the availability of nutrient sources and their contribution to $O$ cf. ovata growth during bloom development and maintenance need to be quantified in marine coastal environments. In the present study, the control of $O$ cf. ovata growth by several nitrogen $(\mathrm{N})$ sources was investigated under controlled conditions, using cultures. The main goal of the present work was to characterize $\mathrm{N}$-uptake of dissolved inorganic and organic sources, using the ${ }^{15} \mathrm{~N}$-labelling technique and taking into account potential interactions between nutrient uptake systems as well as variations with the diel cycle.

\section{Material and methods}

\subsection{Culture conditions}

Two strains of Ostreopsis cf. ovata, MCCV 054 and MCCV 055, were obtained from the Mediterranean Culture Collection of Villefranche (MCCV). They were both isolated in 2014 from Villefranche Bay, South of France $\left(43^{\circ} 41^{\prime} 34.83^{\prime \prime} \mathrm{N}\right.$ and $\left.7^{\circ} 18^{\prime} 31.66^{\prime \prime} \mathrm{E}\right)$, during the same bloom event. Non-axenic stock cultures were grown in modified K/10 medium (originally defined by Keller et al. (1987)), where addition of silicate and Tris base was omitted, phosphorus was added as $\mathrm{KH}_{2} \mathrm{PO}_{4}$ (final concentration of $4 \mu \mathrm{M}$ ) and ZnSO4 was added at a final concentration of $0.08 \mathrm{nM}$. Culture medium was prepared using autoclaved old seawater filtered on $0.2 \mu \mathrm{m}(\mathrm{FSW})$ at salinity 38 . Cultures were maintained at $23^{\circ} \mathrm{C}$, under $250 \mu \mathrm{mol}$ photons $\mathrm{m}^{-2} \mathrm{~s}^{-1}$, with a 16:8 $\mathrm{h}$ light:dark cycle. Stock cultures were grown in batch mode without bubbling, in $15 \mathrm{~mL}$ of culture medium. Culture flasks were maintained in flat culturing conditions in order to optimize the surface area for gas exchange and growth of benthic cells. Before each experiment, one stock culture in exponential phase of growth was 
successively diluted in order to scale up the culture volume from $15 \mathrm{ml}$ (in flask of $25 \mathrm{~cm}^{2}$ surface area) to $350 \mathrm{ml}$ (in flask of $300 \mathrm{~cm}^{2}$ surface area). The final large volume culture was used to inoculate three or four replicated cultures of $350 \mathrm{ml}$. Experiments were run using a set of replicated cultures in exponential phase and characterized by a cell density higher than 1,500 cell $\mathrm{ml}^{-1}$.

\subsection{Micro-algal cell resuspension in low $\mathbf{N}$ medium}

Experiments were conducted under controlled conditions of nitrogen $(\mathrm{N})$ availability in order to help for a precise characterization of $\mathrm{N}$-uptake capabilities of $O$. cf. ovata cells. Each experiment started with the resuspension of micro-algal cells in culture medium where no $\mathrm{NH}_{4}{ }^{+}$or $\mathrm{NO}_{3}{ }^{-}$addition was performed (-N medium). Concentrations of $\mathrm{NH}_{4}{ }^{+}$and $\mathrm{NO}_{3}{ }^{-}$ were determined for the $-\mathrm{N}$ medium used for running the experiments. Full resuspension of O. cf. ovata cells was completed in about $1 \mathrm{~h}$. Cells were collected on an 8 or $10 \mu \mathrm{m}$ mesh size net by gravity filtration, then rinsed with $-\mathrm{N}$ medium before being resuspended in $-\mathrm{N}$ medium. To ensure that the net was not clogged due to mucus accumulation, these collection, rinsing and resuspension steps were performed on successive aliquots of 35 or $40 \mathrm{~mL}$ of culture and a new piece of net was used every four aliquots. A gentle agitation of the net in $\mathrm{N}$ medium did not allow for passive resuspension of $O$. cf. ovata cells. Thus, for each aliquot of culture, micro-algal cells concentrated on the net were collected by pipetting repeatedly and carefully $\sim 1 \mathrm{ml}$ of $-\mathrm{N}$ medium above the net, then this volume was finally poured in a culture flask $\left(75 \mathrm{~cm}^{2}\right.$ surface area) filled with $40 \mathrm{~mL}$ of $-\mathrm{N}$ medium. The resuspension and rinsing steps allowed for the removal of most of the bacteria present in the growth medium and limited their contribution in the resuspended cultures (Raush de Traubenberg and SoyerGobillard, 1990). 
The resuspended culture flasks were kept aside in the culture chamber, under initial culture conditions, during 1-2h before starting the incubations. This lag reduced the potential impact of stress associated with the resuspension step on uptake rates and also contributed to start incubations under really low $\mathrm{N}$ concentrations.

\subsection{Kinetic experiments}

Uptake kinetics of three potential $\mathrm{N}$-sources, nitrate $\left(\mathrm{NO}_{3}{ }^{-}\right)$, ammonium $\left(\mathrm{NH}_{4}{ }^{+}\right)$and urea, were characterized for the two $O$. cf. ovata strains, MCCV 054 and MCCV 055. For each strain, $O$. cf. ovata cells were resuspended from three replicated cultures of $350 \mathrm{ml}$ in exponential phase. Each mother culture allowed for the creation of one series of eight $40 \mathrm{ml}$ samples and was used to characterize the uptake kinetics of one $\mathrm{N}$-source. Incubations started with the addition of ${ }^{15} \mathrm{~N}\left({ }^{15} \mathrm{NO}_{3}{ }^{-},{ }^{15} \mathrm{NH}_{4}{ }^{+}\right.$or ${ }^{15} \mathrm{~N}$-urea $)$ at eight graded concentrations $(0.1,0.2$, $0.5,1,2,3,5$, and $10 \mu \mathrm{mol} \mathrm{N} \mathrm{L} \mathrm{L}^{-1}$ ). Samples were incubated for $1 \mathrm{~h}$ under initial culture conditions. At the end of the incubation, samples were filtered through precombusted $(4 \mathrm{~h}$ at $\left.450^{\circ} \mathrm{C}\right) \mathrm{A} / \mathrm{E}$ filters (Gelman Sciences) and rinsed with $20 \mathrm{~mL}$ of FSW. Filters were dried at $60^{\circ} \mathrm{C}$ overnight and analyzed by EA-IRMS (Elemental Analysis - Isotope Ratio Mass Spectrometry) for measurements of particulate carbon (PC), particulate nitrogen (PN) and ${ }^{15} \mathrm{~N} /{ }^{14} \mathrm{~N}$ isotopic ratios.

An additional experiment was conducted in order to characterize $\mathrm{N}$-urea uptake capabilities of $O$. cf. ovata cells taking into account the potential role of preconditioning effects. Cells of $O$. cf. ovata were grown on a modified K/10 medium containing three potential N-sources: $\mathrm{NO}_{3}{ }^{-}$added at $28.8 \mu \mathrm{mol} \mathrm{N} \mathrm{L}{ }^{-1}$ and $\mathrm{NH}_{4}{ }^{+}$and $\mathrm{N}$-urea added at $5 \mu \mathrm{mol} \mathrm{N}$ $\mathrm{L}^{-1}$. These growth conditions were maintained during several culture transfers in batch mode. Then, one culture of $350 \mathrm{~mL}$ in exponential phase was used for running a replicated kinetic 
experiment, in order to estimate $\mathrm{N}$-urea uptake rates along a concentration gradient of $0-10$ $\mu \mathrm{mol} \mathrm{N} \mathrm{L}{ }^{-1}$.

\subsection{Interaction experiments}

An experiment was run in order to characterize the potential interaction between $\mathrm{NH}_{4}{ }^{+}$ and $\mathrm{NO}_{3}{ }^{-}$uptake. Four replicated cultures of $350 \mathrm{~mL}$ (MCCV 054) were used to carry out two successive series of incubations, one testing the influence of $\mathrm{NH}_{4}{ }^{+}$on the maximal uptake rate of $\mathrm{NO}_{3}{ }^{-}$, and the other the influence $\mathrm{NO}_{3}{ }^{-}$on the maximal uptake rate of $\mathrm{NH}_{4}{ }^{+}$. During each part of the experiment, the uptake rate of one nutrient, added at a reference concentration of $10 \mu \mathrm{mol} \mathrm{N} \mathrm{L} \mathrm{N}^{-1}$, was measured as a function of the increasing concentration of the other nutrient $\left(0,0.1,0.2,0.5,1,2,3,5\right.$, and $\left.10 \mu \mathrm{mol} \mathrm{N} \mathrm{L} \mathrm{L}^{-1}\right)$. For each set, two series of incubations were performed in parallel in order to simultaneously assay uptake rates of both nutrients $\left(\mathrm{NH}_{4}{ }^{+}\right.$and $\left.\mathrm{NO}_{3}{ }^{-}\right)$for all nutritive conditions. These coupled incubations were based on the same nutrient regime, with only one of the two $\mathrm{N}$-sources labeled with ${ }^{15} \mathrm{~N}$ : for one series of samples, the nutrient added under various concentration $\left(0-10 \mu \mathrm{mol} \mathrm{N} \mathrm{L}^{-1}\right)$ was labeled with

${ }^{15} \mathrm{~N}$ and, for the other series of samples, the nutrient added at saturating concentration (10 $\mu$ mol $\mathrm{N} \mathrm{L}^{-1}$ ) was labeled with ${ }^{15} \mathrm{~N}$. Incubations started with the addition of ${ }^{15} \mathrm{NH}_{4}{ }^{+}$or ${ }^{15} \mathrm{NO}_{3}{ }^{-}$ into $40 \mathrm{~mL}$ samples and lasted $1 \mathrm{~h}$. Incubations ended with the filtration of samples through precombusted (4 h at $450^{\circ} \mathrm{C}$ ) A/E filters (Gelman Sciences). Filters were rinsed with $20 \mathrm{~mL}$ of FSW, then dried at $60^{\circ} \mathrm{C}$ overnight. Analyses were run using EA-IRMS in order to obtain measurements of $\mathrm{PN}, \mathrm{PC}$ and ${ }^{15} \mathrm{~N} /{ }^{14} \mathrm{~N}$ isotopic ratios.

\subsection{Diel cycle experiments}

Variations of $\mathrm{NH}_{4}{ }^{+}-$and $\mathrm{NO}_{3}{ }^{-}$-uptake by $O$. cf. ovata cells were investigated over the diel cycle. For each N-source, three replicated cultures of $350 \mathrm{ml}$ (MCCV 054) were used and 
allowed for the preparation of three series of ten resuspended samples, each of them containing $40 \mathrm{~mL}$ of $-\mathrm{N}$ medium. At the beginning of the incubations, all samples were spiked with a solution of ${ }^{15} \mathrm{~N}\left({ }^{15} \mathrm{NH}_{4}{ }^{+}\right.$or $\left.{ }^{15} \mathrm{NO}_{3}{ }^{-}\right)$at $100 \mu \mathrm{mol} \mathrm{N} \mathrm{L}{ }^{-1}$ final concentration and were immediately replaced in the culture chamber under initial conditions. This level of concentration was used to ensure $\mathrm{N}$-sufficient conditions all along the experiment duration. Regular stops in the incubations were done during a $24 \mathrm{~h}$ survey (every $3 \mathrm{~h}$ during light periods and three times during the dark phase). At each stop, three samples were taken, one originating from each of the replicated mother cultures. Cells of $O$. cf. ovata were collected on precombusted $\left(4 \mathrm{~h}\right.$ at $\left.450^{\circ} \mathrm{C}\right) \mathrm{A} / \mathrm{E}$ filters (Gelman Sciences) and rinsed with $20 \mathrm{~mL}$ of FSW. Half of the samples were used to follow nutrient concentrations during the experiment, collecting $20 \mathrm{~mL}$ of the culture filtrate during microalgal cell collection (before the rinsing step). Filters were finally dried at $60^{\circ} \mathrm{C}$ overnight, then analyzed by EA-IRMS in order to obtain measurements of $\mathrm{PN}, \mathrm{PC}$ and ${ }^{15} \mathrm{~N} /{ }^{14} \mathrm{~N}$ isotopic ratios.

\subsection{Cell counts and nutrient analysis}

Growth rate was estimated for each mother culture used for running experiments, from measurements of cell density done just before the resuspension step and $24 \mathrm{~h}$ earlier. These growth rate estimations allowed to verify that $O$. cf. ovata cells were growing under optimal growth conditions when incubations started. For sampling, three $2 \mathrm{~mL}$-aliquots of culture were taken after a gentle mixing of the culture and pooled together before counting. Samples were fixed with acidic lugol solution at $1 \%(\mathrm{vol} / \mathrm{vol})$ final concentration and stored at $+4^{\circ} \mathrm{C}$ until analysis. Cell counts were done in triplicate using a $1 \mathrm{~mL}$ Sedgewick rafter counting chamber. Growth rates were calculated according to Guillard (1973), using the following formula:

$\mu=\frac{\ln (C 2)-\ln (C 1)}{t 2-t 1}$ 
where $\mu$ is the growth rate $\left(d^{-1}\right), C_{1}$ and $C_{2}$ are the cell concentrations at time $1\left(t_{1}, d\right)$ and time $2\left(\mathrm{t}_{2}, \mathrm{~d}\right)$, respectively.

Measurements of $\mathrm{NH}_{4}{ }^{+}$concentrations were performed few hours after sampling, using the fluorometric method (Taylor et al., 2007). Samples for estimations of $\mathrm{NO}_{3}{ }^{-}$ concentration were immediately frozen at $-20^{\circ} \mathrm{C}$ and stored until analysis. Concentrations of $\mathrm{NO}_{3}{ }^{-}$were measured using an automated colourimetry system (Seal Analytical continuous flow AutoAnalyser III, AA3)) as described by Bendschneider and Robienson (1952).

\subsection{N-uptake measurements and kinetic parameters}

For determination of PN, PC and ${ }^{15} \mathrm{~N} /{ }^{14} \mathrm{~N}$ isotopic ratios, EA-IRMS experiments were done with an Elementar Vario Pyro Cube analyzer in $\mathrm{CN}$ mode (combustion oven $920^{\circ} \mathrm{C}$, reduction oven $600^{\circ} \mathrm{C}$ ) coupled to an Isoprime 100 IRMS (Isotope Resolved Mass Spectrometer). Calibration of measurements was performed with certified caffeine (AIEA600) and other laboratory standards (commercially available glycine (Sigma), acetinalide (Merck)).

Uptake rates $\left(V\right.$ in $\left.\mathrm{h}^{-1}\right)$ were calculated from the ${ }^{15} \mathrm{~N}$ enrichment of the samples according to Collos (1987). For kinetic and interaction experiments, relationship between uptake rates and concentrations that showed clear saturating kinetics were modeled using the original or a modified equation of the Michaelis-Menten model. When the ${ }^{15} \mathrm{~N}$-source was added at graded concentrations, uptake data were modeled using the original MichaelisMenten relation:

$V_{\mathrm{N}}=V_{\max -\mathrm{N}} \times[N] /\left(K_{\mathrm{s}}+[N]\right)$

Where $V_{\mathrm{N}}\left(\mathrm{in} \mathrm{h}^{-1}\right)$ is the $\mathrm{N}$-uptake rate under a nutrient concentration of $[N]$ (in $\mu$ mol $\mathrm{N} \mathrm{L}^{-1}$ ), $V_{\text {max-N }}$ is the maximal uptake rate $\left(\right.$ in $\mathrm{h}^{-1}$ ) and $K_{\mathrm{s}}$ is the half-saturation constant (in $\mu$ mol $\mathrm{N} \mathrm{L}^{-}$ $1)$. 
For these kinetics, the initial slope $\alpha$ was also calculated from the uptake rate at the concentration of $0.5 \mu \mathrm{mol} \mathrm{N} \mathrm{L} \mathrm{L}^{-1}$ estimated by the model equation as recommended by Hurd and Dring (1990), and was used as an indicator of the competitive ability of the cells at low substrate concentrations.

For the interaction experiment, the exponential decrease in the uptake rate of one nutrient $(\mathrm{N} 1)$ when increasing the concentration of the other $(\mathrm{N} 2)$ was fitted to the reverse Michaelis-Menten relation (Varela and Harrison, 1999):

$V_{\mathrm{N} 1}=V_{\max -\mathrm{N} 2=0} \times\left(1-\left(I_{\max } \times[N 2] /\left(K_{\mathrm{I}}+[N 2]\right)\right)\right.$

Where the $\mathrm{N}$-uptake rate of the nutrient $\mathrm{N} 1, V_{\mathrm{N} 1}\left(\mathrm{in}^{-1}\right)$, is function of the maximum uptake rate without inhibition $\left(V_{\max -\mathrm{N} 2=0}\right.$, in $\left.\mathrm{h}^{-1}\right)$, the concentration of the inhibitory nutrient [N2] (in $\mu \mathrm{mol} \mathrm{N} \mathrm{L}{ }^{-1}$ ), the maximum inhibition $I_{\max }$ (values from 0 to 1 ) and of the inhibition constant $K_{\mathrm{I}}$ (concentration of $\mathrm{N} 2$ at which $I=I_{\max } / 2$, in $\mu \mathrm{mol} \mathrm{N} \mathrm{L} \mathrm{L}^{-1}$ ).

For the diel cycle experiment, uptake rates during each light and dark period were estimated from linear regressions of isotopic ratios vs. time.

Values of kinetic parameters were obtained from non-linear regressions of data sets, using the Statgraphics Centurion software (Manugistics, Inc.). Statistical tests (significance and comparison of regression slopes) were performed using the same software.

\section{Results}

\subsection{Culture medium and cellular growth}

In terms of nutrient availability, low $\mathrm{N}$-conditions were verified in the culture medium used for running the experiments. The medium used for resuspension and incubation of $O$. cf. ovata cells was characterized by an $\mathrm{NH}_{4}{ }^{+}$concentration of $0.82 \mu \mathrm{mol} \mathrm{N} \mathrm{L}{ }^{-1}(\mathrm{SD} \pm 0.27 \mu \mathrm{mol}$ $\left.\mathrm{N} \mathrm{L}^{-1}\right)$ and $\mathrm{NO}_{3}{ }^{-}$concentration of $1.00 \mu \mathrm{mol} \mathrm{N} \mathrm{L}{ }^{-1}\left(\mathrm{SD} \pm 0.01 \mu \mathrm{mol} \mathrm{N} \mathrm{L}{ }^{-1}\right)$. 
All cultures used for running the experiments were growing exponentially, under similar growth conditions. At resuspension time, the growth rates of replicated cultures were, on average, $0.39 \mathrm{~d}^{-1}, 0.45 \mathrm{~d}^{-1}$ and $0.51 \mathrm{~d}^{-1}$ for the kinetic experiment, the interaction experiment and the diel cycle experiment, respectively. Quantities of particulate organic nitrogen $(\mathrm{PN})$ and carbon $(\mathrm{PC})$ allowed for estimations of $\mathrm{C}: \mathrm{N}$ (atomic) ratio. Mean $\mathrm{C}: \mathrm{N}$ ratios of $12.3(\mathrm{SD} \pm 1.0)$ and $12.5(\mathrm{SD} \pm 0.8)$ were estimated for the strains MCCV 054 and MCCV 055, respectively, from the compilation of data sets obtained during short-term experiments (1h-incubations). Extra-cellular mucilage might have interfered in the precision of these estimations. Trends observed in $\mathrm{C}: \mathrm{N}$ ratios did not allow for a detailed characterization of the coupling between $\mathrm{N}$ - and C-fluxes over the diel cycle.

\subsection{Uptake rates during kinetic experiments}

Variations of ${ }^{15} \mathrm{~N}$-enrichment over 1 h-incubations showed that $O$. cf. ovata cells were able to use dissolved inorganic $\mathrm{N}$-sources $\left(\mathrm{NH}_{4}{ }^{+}\right.$and $\left.\mathrm{NO}_{3}{ }^{-}\right)$and dissolved organic nitrogen (N-urea). Similar saturating kinetic curves were observed for the two strains of $O$. cf. ovata tested, when $\mathrm{NH}_{4}{ }^{+}, \mathrm{NO}_{3}{ }^{-}$or $\mathrm{N}$-urea was added as a unique $\mathrm{N}$-source along a gradient of $0-10$ $\mu$ mol N L ${ }^{-1}$ (Figure 1). Out of the three potential N-sources tested, $O$. cf. ovata cells showed a clear preference pattern following the ranking: $\mathrm{NH}_{4}^{+}>\mathrm{NO}_{3}^{-}>\mathrm{N}$-urea. No potential preconditioning effect influenced this ranking because $O$. cf. ovata cells were grown in $\mathrm{K} / 10$ medium with $\mathrm{NH}_{4}{ }^{+}$and $\mathrm{NO}_{3}{ }^{-}$added as $\mathrm{N}$-sources and an acclimation of cells to the presence of N-urea in the culture medium did not induce a clear modification of $\mathrm{N}$-urea kinetics (Figure 1C). For both strains, on average along the whole gradient, $\mathrm{NH}_{4}{ }^{+}$uptake rate was 4 to 5 times higher than $\mathrm{NO}_{3}{ }^{-}$uptake rate, when $\mathrm{NO}_{3}{ }^{-}$uptake rate was 8 to 9 times higher than $\mathrm{N}$-urea uptake rate. 
Relationships between uptake rates and nutrient concentrations were characterized by the Michaelis-Menten model. Similar estimations of kinetic parameters $\left(V_{\max }, K_{\mathrm{s}}, \alpha\right)$ were obtained for the two strains (Table 1). This similarity allowed to characterize abilities of $O$. cf. ovata cells isolated in the Bay of Villefranche-sur-mer by a maximal uptake rate $\left(V_{\max }\right)$ of $0.021 \mathrm{~h}^{-1}\left(\mathrm{SD} \pm 0.001 \mathrm{~h}^{-1}\right), 0.008 \mathrm{~h}^{-1}\left(\mathrm{SD} \pm 0.003 \mathrm{~h}^{-1}\right), 0.0005 \mathrm{~h}^{-1}\left(\mathrm{SD} \pm 0.0001 \mathrm{~h}^{-1}\right)$ for $\mathrm{NH}_{4}^{+}$, $\mathrm{NO}_{3}{ }^{-}$and N-urea, respectively. The associated $K_{\mathrm{s}}$ values were $0.5 \mu \mathrm{mol} \mathrm{N} \mathrm{L}{ }^{-1}(\mathrm{SD} \pm 0.1 \mu \mathrm{mol}$ $\left.\mathrm{N} \mathrm{L}^{-1}\right), 2.3 \mu \mathrm{mol} \mathrm{N} \mathrm{L}{ }^{-1}\left(\mathrm{SD} \pm 2.1 \mu \mathrm{mol} \mathrm{N} \mathrm{L}{ }^{-1}\right)$ and $0.3 \mu \mathrm{mol} \mathrm{N} \mathrm{L}{ }^{-1}\left(\mathrm{SD} \pm 0.1 \mu \mathrm{mol} \mathrm{N} \mathrm{L}{ }^{-1}\right)$ for $\mathrm{NH}_{4}{ }^{+}, \mathrm{NO}_{3}{ }^{-}$and $\mathrm{N}$-urea, respectively. For the characterization of abilities under low nutrient concentrations, the initial slope of kinetic curves $(\alpha)$ was $0.011 \mathrm{~L} \mu \mathrm{mol} \mathrm{N}^{-1} \mathrm{~h}^{-1}(\mathrm{SD} \pm 0.001 \mathrm{~L}$ $\left.\mu \mathrm{mol} \mathrm{N}{ }^{-1} \mathrm{~h}^{-1}\right), 0.002 \mathrm{~L} \mu \mathrm{mol} \mathrm{N}{ }^{-1} \mathrm{~h}^{-1}\left(\mathrm{SD} \pm 0.001 \mathrm{~L}^{\mathrm{m} m o l ~ N^{-1}} \mathrm{~h}^{-1}\right)$ and $0.0003 \mathrm{~L} \mu \mathrm{mol} \mathrm{N} \mathrm{N}^{-1} \mathrm{~h}^{-1}$ $\left(\mathrm{SD} \pm 0.0001 \mathrm{~L} \mu \mathrm{mol} \mathrm{N}^{-1} \mathrm{~h}^{-1}\right)$ for $\mathrm{NH}_{4}{ }^{+}, \mathrm{NO}_{3}{ }^{-}$and $\mathrm{N}$-urea, respectively.

\subsection{Uptake rates during interaction experiments}

The influence of $\mathrm{NH}_{4}{ }^{+}$on the maximal uptake rate of $\mathrm{NO}_{3}^{-}\left(V_{\text {max-NO3-}}\right)$ was analyzed from estimations of ${ }^{15} \mathrm{NH}_{4}{ }^{+}$and ${ }^{15} \mathrm{NO}_{3}^{-}$-uptake rates after an addition of $10 \mu \mathrm{mol} \mathrm{N} \mathrm{L}{ }^{-1}$ of $\mathrm{NO}_{3}{ }^{-}$and an $\mathrm{NH}_{4}{ }^{+}$concentration varying from 0 to $10 \mu \mathrm{mol} \mathrm{N} \mathrm{L} \mathrm{N}^{-1}$ (Figure 2A). In the presence of $10 \mu \mathrm{mol} \mathrm{N} \mathrm{L}{ }^{-1}$ of $\mathrm{NO}_{3}{ }^{-}$, the relationship between $\mathrm{NH}_{4}{ }^{+}$uptake rate and $\mathrm{NH}_{4}^{+}$ concentration displayed a saturating kinetic (Figure 2A) with a high $V_{\max }$ of $0.034 \mathrm{~h}^{-1}$ and a $K_{\mathrm{s}}$ value $\left(0.7 \mu \mathrm{mol} \mathrm{N} \mathrm{L}{ }^{-1}\right)$ close to estimations done when $\mathrm{NH}_{4}{ }^{+}$was added as the only $\mathrm{N}$-source

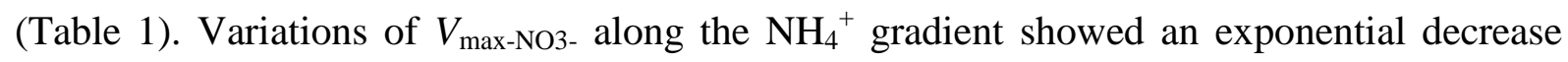
that could be characterized by fitting the data set to the reverse Michaelis-Menten model (2) (Figure 2A). The inhibition parameters generated by the model (Table 1) showed a strong $\mathrm{NH}_{4}{ }^{+}$inhibition of $\mathrm{NO}_{3}{ }^{-}$uptake rate, with a maximum inhibition value of $67 \%$ and a $K_{\mathrm{I}}$ value of $6.2 \mu \mathrm{mol} \mathrm{N} \mathrm{L}{ }^{-1}$. 
Under reverse nutrient conditions (addition of $10 \mu \mathrm{mol} \mathrm{N} \mathrm{L}{ }^{-1}$ of $\mathrm{NH}_{4}{ }^{+}$along a $\mathrm{NO}_{3}^{-}$ gradient of $0-10 \mu \mathrm{mol} \mathrm{N} \mathrm{L}{ }^{-1}$ ), variations of $\mathrm{NO}_{3}{ }^{-}$uptake rates were characterized by kinetic parameters $\left(V_{\max }=0.008 \mathrm{~h}^{-1}, K_{\mathrm{s}}=2.8 \mu \mathrm{mol} \mathrm{N} \mathrm{L}{ }^{-1}\right)$ after fitting the data set to the MichaelisMenten model (1) (Figure 2B, Table 1). Concerning variations of $V_{\max -\mathrm{NH} 4+}$ with increasing $\mathrm{NO}_{3}{ }^{-}$concentration, the reverse Michaelis-Menten model did not converge, however, even if the $\mathrm{NH}_{4}{ }^{+}$uptake rate obtained after addition of $10 \mu \mathrm{mol} \mathrm{N} \mathrm{L}-1$ of $\mathrm{NH}_{4}^{+}$and $10 \mu \mathrm{mol} \mathrm{N} \mathrm{L}-1$ of $\mathrm{NO}_{3}{ }^{-}$appeared to be slightly low Figure $2 \mathrm{~B}$ ). Globally, $\mathrm{NH}_{4}{ }^{+}$uptake rate was stable along the $\mathrm{NO}_{3}{ }^{-}$gradient, with $V_{\max -\mathrm{NH} 4+}=0.026 \mathrm{~h}^{-1}\left(\mathrm{SD} \pm 0.002 \mathrm{~h}^{-1}\right)$.

\subsection{Diel cycle experiment}

After the addition of $100 \mu \mathrm{mol} \mathrm{N} \mathrm{L}{ }^{-1}$ of ${ }^{15} \mathrm{~N}\left({ }^{15} \mathrm{NH}_{4}{ }^{+}\right.$or $\left.{ }^{15} \mathrm{NO}_{3}{ }^{-}\right)$, linear decreases in nutrient concentrations were observed with time for both series of incubations (data not shown). Despite the consumption of nitrogen sources, final concentrations of $\mathrm{NH}_{4}{ }^{+}$and $\mathrm{NO}_{3}{ }^{-}$ in replicated flasks were $\left.84 \mu \mathrm{mol} \mathrm{N} \mathrm{L}{ }^{-1}(\mathrm{SD} \pm 9 \mu \mathrm{mol} \mathrm{N} \mathrm{L})^{-1}\right)$ and $82 \mu \mathrm{mol} \mathrm{N} \mathrm{L}{ }^{-1}(\mathrm{SD} \pm 4 \mu \mathrm{mol}$ $\mathrm{N} \mathrm{L}^{-1}$ ), respectively, after $24 \mathrm{~h}$ of incubation. These estimations showed the maintenance of $\mathrm{N}$ replete conditions over the whole experiment duration (24h).

According to estimations of ${ }^{15} \mathrm{~N}$-enrichment of $O$. cf. ovata cells over the diel cycle, microalgal cells were capable of using both $\mathrm{NH}_{4}{ }^{+}$and $\mathrm{NO}_{3}{ }^{-}$during the light and the dark periods (Figure 3). For both $\mathrm{NH}_{4}{ }^{+}$and $\mathrm{NO}_{3}{ }^{-}$, linear increases in ${ }^{15} \mathrm{~N}$-atom (\%) of $O$. cf. ovata cells were observed with time during each consecutive light and dark periods. During the first light period, trends were highly significant for both $\mathrm{NH}_{4}{ }^{+}$and $\mathrm{NO}_{3}{ }^{-}$(linear regressions with $\mathrm{r}^{2}$ $=0.99, \mathrm{p}<0.001$, Table 2 and Figure 3). Slopes of linear regressions allowed for precise estimations of $\mathrm{N}$-uptake rates and indicated that $\mathrm{NH}_{4}{ }^{+}$-uptake rate was higher $\left(0.032 \mathrm{~h}^{-1}\right)$ than but also close to $\mathrm{NO}_{3}^{-}$-uptake rate $\left(0.030 \mathrm{~h}^{-1}\right)$ during the light period. During the subsequent dark phase, values of ${ }^{15} \mathrm{~N}$-atom $(\%)$ were coherent between replicated flasks and showed an 
increasing trend with time for both $\mathrm{NH}_{4}{ }^{+}$and $\mathrm{NO}_{3}{ }^{-}$(Figure 3). Slopes of linear regressions that modelled dark processes were not significant $\left(r^{2} \geq 0.78, p \geq 0.06\right.$, Table 2$)$, however, suggesting a lack of precision in dark $\mathrm{N}$-uptake rate estimations. From present results, dark uptake rates corresponded to $19 \%$ and $10 \%$ of light uptake rates for $\mathrm{NH}_{4}^{+}$and $\mathrm{NO}_{3}{ }^{-}$, respectively.

\section{Discussion}

Nutrient uptake capabilities of phytoplankton cells are known to vary as a function of cell size (Litchman et al., 2007), nutritional history and physiological status of the cells (Mulholland and Lomas, 2008), growth rates (Maguer et al., 2007), N substrate interactions (Maguer et al., 2007; Jauzein et al., 2008a) and environmental factors such as irradiance and temperature (Lomas and Glibert, 1999; Kudela and Cochlan, 2000). Consequently, it is often difficult to determine taxa-specific differences in uptake capabilities and environmental control on uptake from field studies. Characterization of uptake capabilities under controlled conditions from culture studies gives the opportunity to better understand uptake regulation. Relatively few studies have determined $\mathrm{N}$-uptake kinetics from cells that are nitrogen replete. In previous culture works, kinetic parameters were often characterized for cells under Nlimited conditions or after several days of N-starvation (e.g. Nishikawa et al., 2009; Kwon et al., 2013). Nutrient depletion can lead to transient or surge uptake, however, when an uncoupling between nutrient uptake and growth occurs (Dortch et al., 1982; Mulholland and Lomas, 2008). In the present study, efforts were made at characterizing N-uptake of cells growing under optimal conditions. Experiments started by the resuspension of exponentially growing cells in $-\mathrm{N}$ medium, when physical conditions were optimized to ensure no limitation of uptake capabilities. Ammonium concentrations used to monitor uptake rates 
were also lower than concentrations known to potentially inhibit growth of dinoflagellate cells (Collos and Harrison, 2014; Siu et al., 1997). Thus, patterns and non-linear regressions of data sets obtained allow for the characterization and parameterization of functional responses of $O$. cf. ovata cells to N-sources availability. In particular, values of parameters, such as halfsaturation constants and inhibition parameters, are crucial for ecological modeling and understanding of forcing functions (Tian, 2006). In the present study, estimations were done when uptake of microalgal cells was tightly coupled with growth; values of parameters obtained can be used for the definition of mechanistic formulations that simulate the function for nutrient limitation of $O$. cf. ovata growth.

Nutrient uptake by microalgal cells is an active process, whose response to extracellular nutrient concentration can generally be modelled as that of an enzyme, using Michaelis-Menten kinetics. In the Michaelis-Menten model, the maximum uptake rate $\left(V_{\max }\right)$ and half-saturation constant $\left(K_{\mathrm{s}}\right)$ are often said to be biological parameters, dependent on the number of carrier sites on cell membrane and specific efficiency of each transporter (Aksnes and Egge, 1991; Litchman et al., 2007). Estimations of these parameters, along with the affinity coefficient $\alpha$, have been used to assess the relative preference for different $\mathrm{N}$ substrates or competitive abilities between species under various nutritive conditions (Cochlan et al., 2008; Mulholland and Lomas, 2008). In the present study, kinetic curves were characterized in the range of few $\mu \mathrm{mol} \mathrm{N} \mathrm{L} \mathrm{N}^{-1}$, for two strains isolated during the same bloom event. They show that $O$. cf. ovata cells are able to use dissolved inorganic $\mathrm{N}$-sources $\left(\mathrm{NO}_{3}{ }^{-}\right.$ and $\mathrm{NH}_{4}{ }^{+}$) and dissolved organic sources (N-urea) with a clear preference pattern: this pattern follows the ranking $\mathrm{NH}_{4}{ }^{+}>\mathrm{NO}_{3}{ }^{-}>\mathrm{N}$-urea and was well defined all over the gradient tested $\left(0.1-10 \mu \mathrm{mol} \mathrm{N} \mathrm{L}{ }^{-1}\right)$. Preconditioning effects did not interfere in these trends for neither of the $\mathrm{N}$-sources tested. Results also show that the preferential uptake of $\mathrm{NH}_{4}{ }^{+}$relative to $\mathrm{NO}_{3}{ }^{-}$is accentuated for $O$. cf. ovata cells by an inhibitory effect of $\mathrm{NH}_{4}^{+}$concentration on $\mathrm{NO}_{3}{ }^{-}$ 
uptake capabilities. Conversely, no influence of $\mathrm{NO}_{3}^{-}$availability on $\mathrm{NH}_{4}^{+}$uptake was observed for this species. Repression of $\mathrm{NO}_{3}{ }^{-}$uptake by $\mathrm{NH}_{4}{ }^{+}$has been well studied for many decades for several phytoplankton species (Glibert et al., 2016), but never for benthic dinoflagellates. The maximal inhibition estimated for $O$. cf. ovata cells $\left(I_{\max }=67 \%\right)$ is similar to values reported for other dinoflagellates (Alexandrium minutum, Prorocentrum minimum, Gyrodinium uncatenum) (Lomas and Glibert, 1999; Maguer et al., 2007). The half-inhibition constant $\left(K_{\mathrm{I}}\right)$ estimated for $O$. cf. ovata $\left(6.2 \mu \mathrm{mol} \mathrm{N} \mathrm{L}{ }^{-1}\right)$ appears really high compared to values reported in previous studies, however, in particular for $\mathrm{N}$-sufficient microalgal cells (e.g., Lomas and Glibert, 1999; Maguer et al., 2007); this suggests a low sensitivity of $\mathrm{NO}_{3}{ }^{-}$ uptake of $O$. cf. ovata cells to $\mathrm{NH}_{4}{ }^{+}$concentration, in particular under low $\mathrm{NH}_{4}{ }^{+}$availability.

On a broader point of view, $\mathrm{NH}_{4}{ }^{+}$is commonly found to be the preferred $\mathrm{N}$-source over $\mathrm{NO}_{3}{ }^{-}$and $\mathrm{N}$-urea for phytoplankton uptake (Mulholland and Lomas, 2008; Glibert et al., 2016, and references therein). The preferential use of $\mathrm{NH}_{4}{ }^{+}$is attributed largely to the low energetic demand for its uptake and assimilation (Syrett, 1981). Exceptions have been documented, however, such as the preference of Pseudo-nitzschia australis for $\mathrm{NO}_{3}{ }^{-}$over $\mathrm{NH}_{4}{ }^{+}$and N-urea reported by Cochlan et al. (2008). Most importantly, the preference for $\mathrm{NH}_{4}{ }^{+}$over $\mathrm{NO}_{3}{ }^{-}$may strongly depend on the range of nutrient considered. As well explained and conceptualized by Glibert et al. (2016), the preference for $\mathrm{NH}_{4}{ }^{+} / \mathrm{NO}_{3}{ }^{-}$can be inverted under high nutrient conditions, due to either $(i)$ the toxicity and growth inhibition of high $\mathrm{NH}_{4}{ }^{+}$concentrations and/or $(\mathrm{ii})$ the potential acceleration of $\mathrm{NO}_{3}{ }^{-}$uptake in the presence of $\mathrm{NO}_{3}{ }^{-}$that can lead to biphasic kinetics. In the present study, results suggest that such an acceleration on $\mathrm{NO}_{3}{ }^{-}$uptake occurs for $O$ cf. ovata cells exposed to high $\mathrm{NO}_{3}{ }^{-}$concentrations. Indeed, $\mathrm{NH}_{4}{ }^{+}$uptake rates were 4 to 5 times higher than $\mathrm{NO}_{3}{ }^{-}$uptake rates during kinetic experiments that were conducted in the range $0.1-10 \mu \mathrm{mol} \mathrm{N} \mathrm{L} \mathrm{N}^{-1}$. During the light period of the diel-cycle experiment, estimations of mean $\mathrm{NO}_{3}^{-}$uptake rate $\left(0.030 \mathrm{~h}^{-1}\right)$ were close to 
estimations of mean $\mathrm{NH}_{4}{ }^{+}$uptake rate $\left(0.032 \mathrm{~h}^{-1}\right)$ after addition of $100 \mu \mathrm{mol} \mathrm{N} \mathrm{L}{ }^{-1}$ of $\mathrm{NH}_{4}{ }^{+}$or $\mathrm{NO}_{3}{ }^{-}$, however. This mean $\mathrm{NO}_{3}{ }^{-}$uptake rate obtained under high nitrate concentrations was more than 3 times higher than the $V_{\max }$ value of $0.008 \mathrm{~h}^{-1}$ estimated in the range $0.1-10 \mu \mathrm{mol}$ $\mathrm{N} \mathrm{L}^{-1}$. Such variations in $\mathrm{N}$-uptake capabilities are consistent with the existence of a twocomponent $\mathrm{NO}_{3}^{-}$uptake system, involving a high-affinity low-capacity constitutive component and a low-affinity high capacity inducible uptake component (Glibert et al., 2016). Results obtained in the present study are consistent with the threshold of about $60 \mu \mathrm{mol} \mathrm{N} \mathrm{L}{ }^{-1}$ that was reported for the transition between biphasic kinetics of $\mathrm{NO}_{3}{ }^{-}$uptake for several phytoplankton species (Collos et al., 1992; Lomas and Glibert, 2000).

The monitoring of $\mathrm{N}$-uptake rates done over the diel cycle allows for the characterization of dark N-uptake capability of $O$ cf. ovata under $\mathrm{N}$-sufficient conditions. Dark uptake of $\mathrm{N}$ compounds is commonly observed in marine waters (e.g. Cochlan et al., 1991; Fan and Glibert, 2005; Maguer et al., 2015). For photosynthetic cells, nutrient uptake and assimilation in darkness occurs at the expense of previously accumulated carbon that will supply dark processes with energy (ATP), reductant $(\mathrm{NAD}(\mathrm{P}) \mathrm{H})$ and C-skeletons (Turpin, 1991). Photosynthetic carbon can be stored in excess during the light period into C-rich and N-free macromolecules, such as carbohydrates (Clark and Flynn, 2002; Granum et al., 2002) or neutral lipids (Fabrégas et al., 2002). Detailed observations of morphological and metabolic features $O$. cf. ovata cells revealed that their cytoplasm is often full of neutral lipid droplets, in all stages of growth under $\mathrm{N}$-sufficient conditions (Honsell et al., 2013). This suggests a potential for C-storage strategies that could support dark processes. Various taxonomic groups of phytoplankton, including dinoflagellates, prymnesiophytes and diatoms, carry out uptake at night under N-sufficient conditions (e.g. Paasche et al., 1984; Clark et al., 2002; Needoba and Harrison, 2004), with reported dark:light (D/L) uptake ratios ranging from $1 \%$ to $75 \%$ for $\mathrm{NO}_{3}{ }^{-}$and from $21 \%$ to $100 \%$ for $\mathrm{NH}_{4}{ }^{+}$(Jauzein et al., 2011, and references therein). With D/L 
uptake ratios of $10 \%$ and $19 \%$ measured for $\mathrm{NO}_{3}{ }^{-}$and $\mathrm{NH}_{4}{ }^{+}$in the present study, $O$. cf. ovata shows low capabilities for $\mathrm{N}$-uptake in darkness, at least under $\mathrm{N}$-sufficient conditions. Thus, the lipid storage strategy noted by Honsell et al. (2013) has to be explored further through additional experiments to define its implications in the species competitiveness. As dark Nuptake processes have been shown to be enhanced under N-limited conditions (Paasche et al., 1984; Turpin, 1991), it could also be interesting to complete the characterization of dark Nuptake capabilities of $O$. cf. ovata testing $\mathrm{N}$-limited conditions and/or in situ measurements.

According to present results, ability to take up nutrients in darkness cannot be seen as a competitive advantage for $O$. cf. ovata. Additional information about species competitiveness can be defined from nutrient uptake kinetic parameters (e.g. Smayda, 1997; Litchman et al., 2007). On a broad point of view, reviews of parameter values reported in both field studies and experimental works show that dinoflagellates have generally higher $K_{\mathrm{s}}$ for DIN than diatoms (Smayda, 1997; Kudela et al., 2010). Diatoms were also characterized by higher carbon-specific $V_{\max }$ (values standardized by $\mathrm{C}$ units in order to diminish the effect of cell size) for $\mathrm{NO}_{3}{ }^{-}$than other taxa, including dinoflagellates (Litchman et al., 2007). Thus, a general trend of low competitive abilities for acquisition of DIN can be defined for dinoflagellates that puts emphasis on the contribution of organic matter in fueling dinoflagellate blooms in oligotrophic or mesotrophic coastal waters (e.g. Collos et al., 2004).

For the benthic compartment in particular, studies reporting uptake parameters are rare. Estimations of $\mathrm{NO}_{3}{ }^{-}$uptake kinetics were done for several species of benthic diatoms by Kwon et al. (2013) and for O. cf. ovata by Pistocchi et al. (2014). These studies report surprisingly high $K_{\mathrm{s}}$ values (ranging from $6.75 \mu \mathrm{mol} \mathrm{N} \mathrm{L}{ }^{-1}$ to $9.29 \mu \mathrm{mol} \mathrm{N} \mathrm{L}{ }^{-1}$ ) compared to literature on planktonic species (Kudela et al., 2010). For $O$. cf. ovata, $K_{\mathrm{s}}$ value reported by Pistocchi et al. (2014) $\left(8.4 \mu \mathrm{mol} \mathrm{N} \mathrm{L} \mathrm{N}^{-1}\right)$ is strongly higher than values $\left(<4 \mu \mathrm{mol} \mathrm{N} \mathrm{L} \mathrm{N}^{-1}\right)$ obtained in the present study for strains isolated from French coastal waters. Strong 
differences in $\mathrm{N}$-uptake abilities can be observed between strains of the same species (Jauzein et al., 2008b). It has also to be noted that some methodological choices can partly explain the high level of $K_{\mathrm{s}}$ reported in Kwon et al. (2013) and Pistocchi et al. (2014) for $\mathrm{NO}_{3}{ }^{-}$uptake of benthic species. These studies were conducted on a large $\mathrm{NO}_{3}{ }^{-}$concentration gradient, ranging from $1 \mu \mathrm{mol} \mathrm{N} \mathrm{L} \mathrm{L}^{-1}$ to $100 \mu \mathrm{mol} \mathrm{N} \mathrm{L}{ }^{-1}$, when kinetic experiments of the present study were run on 0.1-10 $\mu \mathrm{mol} \mathrm{N} \mathrm{L}{ }^{-1}$. Collos et al. (2005) pooled data from 20 different studies dealing with phytoplankton uptake and showed a direct increase in $K_{\mathrm{s}}$ values with maximal $\mathrm{NO}_{3}{ }^{-}$ concentration used in the respective studies. This correlation can be explained by an acclimation of microalgal cells to high $\mathrm{NO}_{3}{ }^{-}$concentrations coming from the existence of multiphasic uptake systems (Collos et al., 2005; Glibert et al., 2016); as explained above, such a biphasic system is suspected for $O$. cf. ovata. Thus, kinetic parameters estimated by Kwon et al. (2013) and Pistocchi et al. (2014) are probably representative of microalgal cell responses to high nutrient availability, but might not provide an appropriate representation of uptake capabilities under low $\mathrm{N}$-conditions, making these results hardly comparable to the present study.

Uptake kinetics are also known to potentially vary with N-history and physiological status of microalgal cells (Mulholland and Lomas, 2008). When compiling exclusively results obtained from actively growing cultures, kinetic parameter values determined for $\mathrm{NH}_{4}{ }^{+}, \mathrm{NO}_{3}{ }^{-}$ and $\mathrm{N}$-urea uptake by $O$. cf. ovata in the present study are in accordance with values reported for other planktonic dinoflagellates (Table 3). For $\mathrm{NO}_{3}{ }^{-}$, the compilation of these data sets also highlights higher $V_{\max }$ for diatoms compared to dinoflagellates, when no pattern can be defined for $K_{\mathrm{s}}$ (Table 3).

In the Bay of Villefranche-sur-mer (South of France), nutritive conditions can be seen as oligotrophic to mesotrophic (Selmer et al., 1993). Recent blooms of O. cf. ovata in this bay were observed when $\mathrm{NH}_{4}{ }^{+}, \mathrm{NO}_{3}{ }^{-}$and $\mathrm{N}$-urea concentrations ranged between $0.04-0.27 \mu \mathrm{mol}$ 
$\mathrm{N} \mathrm{L}^{-1}, 0.20-2.12 \mu \mathrm{mol} \mathrm{N} \mathrm{L} \mathrm{N}^{-1}$ and $0.3-2.25 \mu \mathrm{mol} \mathrm{N} \mathrm{L}{ }^{-1}$, respectively (data not shown). Under such low availability in $\mathrm{N}$-sources, affinity $\left(K_{\mathrm{s}}\right)$ more than velocity $\left(V_{\max }\right)$ should control species competitiveness. In the present study, values of $K_{\mathrm{s}}$ estimated for $\mathrm{NH}_{4}{ }^{+}, \mathrm{NO}_{3}{ }^{-}$ and $\mathrm{N}$-urea uptake by $O$. cf. ovata are in the upper part of these ranges of in situ concentrations. This suggests a good adaptation of the cells to field conditions but not a strong affinity strategy. To go further on the definition of specific competitive abilities, affinity for $\mathrm{N}$-sources can also be compared to other taxa taking into account field studies and other culture works. Indeed, characterization of $\mathrm{N}$-uptake kinetics of microalgal cells as a function of N-limitation did not always show variations of $K_{\mathrm{s}}$ with $\mathrm{N}$-status or cell nutritional history (Hu et al., 2014; Maguer et al., 2007). According to the review done by Kudela et al. (2010), $O$. cf. ovata shows relatively high $K_{\mathrm{s}}$ (low affinity) for $\mathrm{NO}_{3}{ }^{-}$, as most of the dinoflagellates do, but a low $K_{\mathrm{s}}$ for $\mathrm{NH}_{4}{ }^{+}$compared to both dinoflagellates and diatoms. This defines strong competitive abilities of $O$. cf. ovata for $\mathrm{NH}_{4}{ }^{+}$uptake under low $\mathrm{N}$-conditions, like the ones encountered during bloom seasons in the Bay of Villefranche-sur-mer. Mixotrophic abilities of $O$. cf. ovata have not been fully characterized yet and are still a matter of debate (Escalera et al., 2014). Current results characterize the potential use of N-urea as a source of labile DON for $O$. cf. ovata cells. According to uptake capabilities and ranges of in situ conditions, contribution of $\mathrm{N}$-urea to growth of $O$. cf. ovata in Villefranche-sur-mer Bay is probably low compared to DIN sources, even if this source can be rapidly regenerated in the water column (Lomas et al., 2002). Out of the three $\mathrm{N}$-sources tested in the present study, the main $\mathrm{N}$-source fueling blooms $O$. cf. ovata in the Bay of Villefranche-sur-mer is probably $\mathrm{NH}_{4}{ }^{+}$, a recycled $\mathrm{N}$-source for which $O$. cf. ovata showed highest uptake rates and good competitive abilities. 


\section{Conclusions}

The present study provides a detailed parameterization of $\mathrm{N}$-uptake by $O$. cf. ovata Kinetic and inhibition parameters can be used for the definition of mechanistic formulations in order to simulate growth limitation by nutrient availability. Ability to take up nutrients in darkness could not be defined as a competitive advantage for $O$. cf. ovata during exponential growth. Conversely, a strong affinity for $\mathrm{NH}_{4}{ }^{+}$was observed for $O$. cf. ovata cells and may partly explain the success of this species during the summer season in the Bay of Villefranche-sur-mer (France). Further studies will be necessary to clarify the role of organic matter in growth of $O$. cf. ovata cells during bloom development and maintenance. It could also be interesting to better characterize links between $\mathrm{C}$ fluxes and other metabolic processes in $O$. cf. ovata cells, trying to define for example the potential role of the lipid storage strategy in terms of species competitiveness.

\section{Acknowledgements}

The authors are grateful to Sophie Marro for isolating and maintaining the algal strains. Those experiments were done with the financial assistance of the European Union under the ENPI CBC Mediterranean Sea Basin Programme, within the project M3-HABs (Project Reference Number: IIB/ 2.1/0096). The authors also wish to thank the French National Project ANR

OCEAN 15 for its contribution for the financial support and the fruitful discussions with project members. Our group is part of the national French GDR PHYCOTOX (CNRS and Ifremer). The authors also have deep thoughts for Yves Collos who inspired this work. 


\section{References}

Accoroni, S., Romagnoli, T., Colombo, F., Pennesi, C., Di Camillo, C.G., Marini, M., Battocchi, C., Ciminiello, P., Dell'Aversano, C., Dello Iacovo, E., Fattorusso, E., Tartaglione, L., Penna, A., Totti, C., 2011. Ostreopsis cf. ovata bloom in the northern Adriatic Sea during summer 2009: Ecology, molecular characterization and toxin profile. Mar. Pol. Bull. 62, 2512-2519.

Accoroni, S., Romagnoli, T., Pichierri, S., Totti, C., 2014. New insights on the life cycle stages of the toxic benthic dinoflagellate Ostreopsis cf. ovata. Harmful Algae 34, 7-16.

Accoroni, S., Glibert, P.M., Pichierri, S., Romagnoli, T., Marini, M., Totti, C., 2015. A conceptual model of annual Ostreopsis cf. ovata blooms in the northern Adriatic Sea based on the synergic effects of hydrodynamics, temperature, and the N:P ratio of water column nutrients. Harmful Algae 45, 14-25.

Accoroni, S., Totti, C., 2016. The toxic benthic dinoflagellates of the genus Ostreopsis in temperate areas: a review. Advances in Oceanography and Limnology 7(1), 1-15.

Aksnes, D.L., Egge, J.K., 1991. A theoretical model for nutrient uptake in phytoplankton. Mar. Ecol. Prog. Ser. 70, 65-72.

Aligizaki, K., Nikolaidis, G., 2006. The presence of the potentially toxic genera Ostreopsis and Coolia (Dinophyceae) in the north Aegean sea, Greece. Harmful Algae 5, 717-730.

Barone, R., 2007. Behavioural trait of Ostreopsis ovata (Dinophyceae) in Mediterranean rock pools: the spider's strategy. Harmful Algae News 33, 1-3.

Bendschneider, K., Robinson, R.J., 1952. A new spectrophotometric method for the determination of nitrite in sea water. J. Mar. Res. 11, 87-96.

Biré, R., Trotereau, S., Lemée R., Oregioni, D., Delpont, C., Krys, S., Guérin, T., 2015. Hunt for palytoxins in a wide variety of marine organisms harvested in 2010 on the French Mediterranean coast. Mar. Drugs 13, 5425-5446. 
Brescianini, C., Grillo, C., Melchiorre, N., Bertolotto, R., Ferrari, A., Vivaldi, B., Icardi, G., Gramaccioni, L., Funari, E., Scardala, S., 2006. Ostreopsis ovata algal blooms affecting human health in Genova, Italy, 2005 and 2006. Eurosurveillance 11, e060907.3.

Brissard, C., Herrenknecht, C., Séchet, V., Hervé, F., Pisapia, F., Harcouet, J., Lemée, R., Chomérat, N., Hess, P., Amzil, Z., 2014. Complex toxin profile of French Mediterranean Ostreopsis cf. ovata strains, seafood accumulation and ovatoxins prepurification. Mar. Drugs 12, 2851-2876.

Burkholder, J.M., Glibert, P.M., Skelton, H.M., 2008. Mixotrophy, a major mode of nutrition for harmful algal species in eutrophic waters. Harmful Algae 8, 77-93.

Ciminiello, P., Dell'Aversano, C., Iacovo, ED., Fattorusso, E., Forino, M., Tartaglione, L., Benedettini, G., Onorari, M., Serena, F., Battocchi, C., et al., 2014. First finding of Ostreopsis cf. ovata toxins in marine aerosols. Environ. Sci. Technol. 48, 3532-3540.

Clark, D.R., Flynn, K.J., 2002. N-assimilation in the noxious flagellate Heterosigma carterae (Raphidophyceae): dependence on light, N-source, and physiological state. J. Phycol. $38,503-512$.

Clark, D.R., Flynn, K.J., Owens, N.J.P., 2002. The large capacity for dark nitrate assimilation in diatoms may overcome nitrate limitation of growth. New Phytol. 155, 101-108.

Cochlan, W.P., Harrison, P.J., Denman, K.L., 1991. Diel periodicity of nitrogen uptake by marine phytoplankton in nitrate-rich environments. Limnol. Oceanogr. 36, 1689-1700.

Cochlan, W.P., Herndon, J., Kudela, R.M., 2008. Inorganic and organic nitrogen uptake by the toxigenic diatom Pseudo-nitzschia australis (Bacillariophyceae). Harmful Algae 8, 111-118.

Cohu, S., Mangialajo, L., Thibaut, T., Blanfuné, A., Marro, S., Lemée, R., 2013. Proliferation of the toxic dinoflagellate Ostreopsis cf. ovata in relation to depth, biotic substrate and environmental factors in the North West Mediterranean Sea. Harmful Algae 24, 32-44. 
Collos, Y. 1987. Calculations of N-15 uptake rates by phytoplankton assimilating one or several nitrogen sources. Appl. Radiat. Isot. 38, 275-82.

Collos, Y., Siddiqi, M.Y., Wang, M.Y., Glass, A.D.M., Harrison, P.J., 1992. Nitrate uptake kinetics by two marine diatoms using the radioactive tracer ${ }^{15}$ N. J. Exp. Mar. Biol. Ecol. $163,251-260$.

Collos, Y., Gagne, C., Laabir, M., Vaquer, A., Cecchi, P., Souchu, P., 2004. Nitrogenous nutrition of Alexandrium catenella (Dinophyceae) in cultures and in Thau Lagoon, Southern France. J. Phycol. 40, 96-103.

Collos, Y., Vaquer, A., Souchu, P., 2005. Acclimation of nitrate uptake by phytoplankton to high substrate levels. J. Phycol. 41, 466-478.

Collos, Y., Harrison, P.J., 2014. Acclimation and toxicity of high ammonium concentrations to unicellular algae. Mar. Pollut. Bull. 80, 8-23.

Dortch, Q., Clayton, J.R., Thoresen, S.S., Bressler, S.L., Ahmed, S.I., 1982. Response of marine phytoplankton to nitrogen deficiency: Decreased nitrate uptake vs enhanced ammonium uptake. Mar. Biol. 70, 13-19.

Escalera, L., Benvenuto, G., Scalco, E., Zingone, A., Montresor, M., 2014. Ultrastructural Features of the Benthic Dinoflagellate Ostreopsis cf. ovata (Dinophyceae). Protist 165, 260-274.

Fábregas, J., Maseda, A., Domínguez, A., Ferreira, M., Otero, A., 2002. Changes in the cell composition of the marine microalga, Nannochloropsis gaditana, during a light:dark cycle. Biotechnol. Lett. 24, 1699-1703.

Fan, C., Glibert, P.M., Burkholder, J.M., 2003. Characterization of the affinity for nitrogen, uptake kinetics, and environmental relationships for Prorocentrum minimum in natural blooms and laboratory cultures. Harmful Algae 2, 283-299. 
Fan, C., Glibert, P.M., 2005. Effects of light on nitrogen and carbon uptake during a Prorocentrum minimum bloom. Harmful Algae 4, 629-641.

Faust, M.A., Morton, S.L., Quod, J.P., 1996. Further study of marine dinoflagellates: the genus Ostreopsis (Dinophyceae). J. Phycol. 32, 1053-1065.

Glibert, P.M., Wilkerson, F.P., Dugdale, R.C., Raven, J.A., Dupont, C.L., Leavitt, P.R., Parker, A.E., Burkholder, J.M., Kana, T.M., 2016. Pluses and minuses of ammonium and nitrate uptake and assimilation by phytoplankton and implications for productivity and community composition, with emphasis on nitrogen-enriched conditions. Limnol. Oceanogr. 61, 165-197.

Gorbi, S., Avio, G.C., Benedetti, M., Totti, C., Accoroni, S., Pichierri, S., Bacchiocchi, S., Orletti, R., Graziosi, T., Regoli, F., 2013. Effects of harmful dinoflagellate Ostreopsis cf. ovata exposure on immunological, histological and oxidative responses of mussels Mytilus galloprovincialis. Fish Shellfish Immunol. 35, 941-950.

Granum, E., Kirkvold, S., Myklestad, S.M., 2002. Cellular and extracellular production of carbohydrates and amino acids by the marine diatom Skeletonema costatum: diel variations and effects of N depletion. Mar. Ecol. Prog. Ser. 242, 83-94.

Guidi-Guilvard, L.D., Gasparini, S., Lemée, R., 2012. The negative impact of Ostreopsis cf. ovata on phytal meiofauna from the coastal NW Mediterranean. Cryptogamie, Algologie 33(2), 121-128.

Guillard, R.R.L., 1973. Division rates. In: Stein, J. R. (Ed.), Handbook of phycological methods. Culture methods and growth measurements. Cambridge University Press, Cambridge, UK, pp. 289-311.

Herndon, J., Cochlan, W.P., 2007. Nitrogen utilization by the raphidophyte Heterosigma akashiwo: Growth and uptake kinetics in laboratory cultures. Harmful Algae 6, 260270. 
Honsell, G., Bonifacio, A., De Bortoli, M., Penna, A., Battocchi, C., Ciminiello, P., Dell'Aversano, C., Fattorusso, E., Sosa, A., Yasumoto, T., Tubaro, A., 2013. New insights on cytological and metabolic features of Ostreopsis cf. ovata Fukuyo (Dinophyceae): a multidisciplinary approach. PLoS ONE 8 (2): e57291.

Hu, Z., Duan, S., Xu, N., Mulholland, M.R., 2014. Growth and nitrogen uptake kinetics in cultured Prorocentrum donghaiense. PLoS ONE 9(4): e94030. doi:10.1371/journal.pone.0094030.

Hurd, C.L., Dring, M. J., 1990. Phosphate uptake by intertidal algae in relation to zonation and season. Mar. Biol. 107, 281-289.

Jauzein, C., Loureiro, S., Garcés, E., Collos, Y., 2008a. Interactions between ammonium and urea uptake by five strains of Alexandrium catenella (Dinophyceae) in culture. Aquat. Microb. Ecol. 53, 271-280.

Jauzein, C., Collos, Y., Garcés, E., Vila, M., Maso, M., 2008b. Short-term temporal variability of ammonium and urea uptake by Alexandrium catenella (Dinophyta) in cultures. J. Phycol. 44, 1136-1145.

Jauzein, C., Collos, Y., Laabir, M., Vaquer, A., 2011. Dark metabolism and carbon-nitrogen uncoupling in the toxic dinoflagellate Alexandrium catenella (Dinophyceae). Harmful Algae 11, 73-80.

Keller, M.D., Selvin, R.C., Claus, W., Guillard, R.R.L., 1987. Media for the culture of oceanic ultraphytoplankton. J. Phycol. 23 (4), 633-638.

Kudela, R.M., Cochlan, W.P., 2000. Nitrogen and carbon uptake kinetics and the influence of irradiance for a red tide bloom off southern California. Aquat. Microb. Ecol. 21, 31-47.

Kudela, R.M., Seeyave, S., Cochlan, W.P., 2010. The role of nutrients in regulation and promotion of harmful algal blooms in upwelling systems. Prog. Oceanogr. 85, 122-135. 
Kwon, H.K., Oh, S.J., Yang, H-S., 2013. Growth and uptake kinetics of nitrate and phosphate by benthic microalgae for phytoremediation of eutrophic coastal sediments. Bioresource Technol. 129, 387-395.

Li, J., Glibert, P.M., Alexander, J.A., 2011. Effects of ambient DIN:DIP ratio on the nitrogen uptake of harmful dinoflagellate Prorocentrum minimum and Prorocentrum donghaiense in turbidistat. Chin. J. Oceanol. Limn. 29 (4), 746-761.

Litchman, E., Klausmeier, C.A., Schofield, O.M., Falkowski, P.G., 2007. The role of functional traits and trade-offs in structuring phytoplankton communities: scaling from cellular to ecosystem level. Ecol. Lett. 10, 1170-1181.

Lomas, M.W., Glibert P.M., 1999. Interactions between NH4+ and NO3- uptake and assimilation: comparison of diatoms and dinoflagellates at several growth temperatures. Mar. Biol. 133, 541-551.

Lomas, M.W., Glibert, P.M., 2000. Comparisons of nitrate uptake, storage, and reduction in marine diatoms and flagellates. J. Phycol. 36, 903-913.

Lomas, M.W., Trice, T.M., Glibert, P.M., Bronk, D.A., McCarthy, J.J., 2002. Temporal and spatial dynamics of urea uptake and regeneration rates and concentrations in Chesapeake Bay. Estuaries. 25 (3), 469-482.

Maguer, J.-F., L’Helguen, S., Madec, C., Labry, C., Le Corre, P., 2007. Nitrogen uptake and assimilation kinetics in Alexandrium minutum (Dynophyceae): effects of N-limited growth rate on nitrate and ammonium interactions. J. Phycol. 43, 295-303.

Maguer, J.-F., L'Helguen, S., Waeles, M., 2015. Effects of mixing-induced irradiance fluctuations on nitrogen uptake in size-fractionated coastal phytoplankton communities. Estuar. Coast. Shelf S. 154, 1-11.

Mangialajo, L., Bertolotto, R., Cattaneo-Vietti, R., Chiantore, M., Grillo, C., Lemée, R., Melchiorre, N., Moretto, P., Povero, P., Ruggieri, N., 2008. The toxic benthic 
dinoflagellate Ostreopsis ovata: Quantification of proliferation along the coastline of Genoa, Italy. Mar. Pollut. Bull. 56, 1209-1214.

Mangialajo, L., Ganzin, N., Accoroni, S., Asnaghi, V., Blanfuné, A., Cabrini, M., CattaneoVietti, R., Chavanon, F., Chiantore, M., Cohu, S., Costa, E., Fornasaro, D., Grossel, H., Marco-Miralles, F., Masó, M., Reñé, A., Rossi, A.M., Sala, M.M., Thibaut, T., Totti, C., Vila, M., Lemé e, R., 2011. Trends in Ostreopsis proliferation along the Northern Mediterranean coasts. Toxicon 57 (3), 408-420.

Mulholland, M.R., Lomas, M.W., 2008. Nitrogen uptake and assimilation. In: Capone, D.G., Bronk, D.A., Mulholland, M.R., Carpenter, E.J. (Eds.), Nitrogen in the marine environment, second ed. Elsevier Inc. Burlington, MA. pp. 303-384.

Needoba, J.A., Harrison, P.J., 2004. Influence of low light and a light:dark cycle on NO3 uptake, intracellular NO3, and nitrogen isotope fractionation by marine phytoplankton. J. Phycol. 40, 505-516.

Nishikawa, T., Tarutani, K., Yamamoto, T., 2009. Nitrate and phosphate uptake kinetics of the harmful diatom Eucampia zodiacus Ehrenberg, a causative organism in the bleaching of aquacultured Porphyra thalli. Harmful Algae 8, 513-517.

Paasche, E., Bryceson, I., Tangen, K., 1984. Interspecific variation in dark nitrogen uptake by dinoflagellates. J. Phycol. 20, 394-401.

Pagliara, P., Caroppo, C., 2012. Toxicity assessment of Amphidinium carterae, Coolia cfr. monotis and Ostreopsis cfr. ovata (Dinophyta) isolated from the northern Ionian Sea (Mediterranean Sea). Toxicon 60, 1203-1214.

Parsons, ML., Preskitt, LB., 2007. A survey of epiphytic dinoflagellates from the coastal waters of the island of Hawai’ i. Harmful Algae 6, 658-669.

Parsons, M.L, Aligizaki, K., Dechraoui Bottein, M.Y., Fraga, S., Morton, S.L., Penna, A., Rhodes, L., 2012. Gambierdiscus and Ostreopsis: Reassessment of the state of 
knowledge of their taxonomy, geography, ecophysiology, and toxicology. Harmful Algae. 14, 107-129.

Pistocchi, R., Pezzolesi, L., Guidi, F., Vanucci, S., Guerrini, F., Pinna, A., 2014. Inorganic nutrients uptake and organic phosphorus utilization by Ostreopsis cf. ovata. In: Proceedings of 16th ICHA conference. pp. 147-150.

Rausch de Traubenberg, C., Soyer-Gobillard, M.O., 1990. Bacteria associated with a photosynthetic dinoflagellate in culture. Symbiosis 8, 117-133.

Rhodes, L., Adamson, J., Suzuki, T., Briggs, L., Garthwaite, I., 2000. Toxic marine epiphytic dinoflagellates, Ostreopsis siamensis and Coolia monotis (Dinophyceae), in New Zealand. New Zeal. J. Mar. Fresh. 34, 371-383.

Rhodes, L., 2011. World-wide occurrence of the toxic dinoflagellate genus Ostreopsis Schmidt. Toxicon 57 (3), 400-407.

Rossi, R., Castellano, V., Scalco, E., Serpe, L., Zingone, A., Soprano, V., 2010. New palytoxin-like molecules in Mediterranean Ostreopsis cf. ovata (dinoflagellates) and in Palythoa tuberculosa detected by liquid chromatography-electrospray ionization timeof-flight mass spectrometry. Toxicon 56 (8), 1381-1387.

Scalco, E., Brunet, C., Marino, F., Rossi, R., Soprano, V., Zingone, A., Montresor, M., 2012. Growth and toxicity responses of Mediterranean Ostreopsis cf. ovata to seasonal irradiance and temperature conditions. Harmful Algae 17, 25-34.

Selina, M.S., Morozova, T.V., Vyshkvartsev, D.I., Orlova, T.Y., 2014. Seasonal dynamics and spatial distribution of epiphytic dinoflagellates in Peter the Great Bay (Sea of Japan) with special emphasis on Ostreopsis species. Harmful Algae 32, 1-10.

Selmer, J.-S., Ferrier-Pages, C., Celario, C., Rassoulzadegan, F., 1993. New and regenerated production in relation to the microbial loop in the NW Mediterranean Sea. Mar. Ecol. Prog. Ser. 100, 71-83. 
Siu, G.K.Y., Young, M.L.C., Chan, D.K.O., 1997. Environmental and nutritional factors which regulate population dynamics and toxin production in the dinoflagellate Alexandrium catenella. Hydrobiologia 352, 117-140.

Smayda, T.J., 1997. Harmful algal blooms: Their ecophysiology and general relevance to phytoplankton blooms in the sea. Limnol. Oceanogr. 42 (5), 1137-1153.

Syrett, P.J., 1981. Nitrogen metabolism of microalgae. Can. Bull. Fish. Aquat. Sci. 210, 182210.

Taniyama, S., Arakawa, O., Terada, M., Nishio, S., Takatani, T., Mahmud, Y., Noguchi, T., 2003. Ostreopsis sp., a possible origin of palytoxin (PTX) in parrotfish Scarus ovifrons. Toxicon 42, 29-33.

Taylor, B.W., Keep, C.F., Hall, R.O., Jr., Koch, B.J., Tronstad, L.M., Flecker, A.S., Ulseth, A.J., 2007. Improving the fluorometric ammonium method: matrix effects, background fluorescence, and standard additions. J. N. Am. Benthol. Soc., 26(2), 167-17.

Tian, R.C., 2006. Toward standard parameterizations in marine biological modeling. Ecol. Model. 193, 363-386.

Totti, C., Accoroni, S., Cerino, F., Cucchiari, E., Romagnoli, T., 2010. Ostreopsis ovata bloom along the Conero Riviera (northern Adriatic Sea): Relationships with environmental conditions and substrata. Harmful Algae 9:233-239.

Turpin, D.H., 1991. Effects of inorganic $\mathrm{N}$ availability on algal photosynthesis and carbon metabolism. J. Phycol. 27, 14-20.

Uchida, H., Taira, Y., Yasumoto, T., 2013. Structural elucidation of palytoxin analogs produced by the dinoflagellate Ostreopsis ovata IK2 strain by complementary use of positive and negative ion liquid chromatography/ quadrupole time-of-flight mass spectrometry. Rapid Commun. Mass Spectrom. 27, 1999-2008. 
Varela, D.E., Harrison, P.J., 1999. Effect of ammonium on nitrate utilization by Emiliania huxleyi, a coccolithophore from the oceanic northeastern Pacific. Mar. Ecol. Prog. Ser. $186,67-74$.

Vila, M., Garcés, E., Masó, M., 2001. Potentially toxic epiphytic dinoflagellates assemblages on macroalgae in the NW Mediterranean. Aquat. Microb. Ecol. 26 (1), 51-60.

Vila, M., Abós-Herràndiz, R., Isern-Fontanet, J., Àlvarez, J., Berdalet, E., 2016. Establishing the link between Ostreopsis cf. ovata blooms and human health impacts using ecology and epidemiology. Scientia Marina 80 (S1), 107-115. 


\section{Figures}

Figure 1. Kinetic curves of $\mathrm{NH}_{4}{ }^{+}, \mathrm{NO}_{3}{ }^{-}$and $\mathrm{N}$-urea uptake for Ostreopsis cf. ovata. Data points show variations of $\mathrm{NH}_{4}{ }^{+}, \mathrm{NO}_{3}{ }^{-}$and $\mathrm{N}$-urea uptake rates as a function of each respective nutrient concentration for the French strains MCCV 054 (A) and MCCV 055 (B). Detailed representations of variations of $\mathrm{N}$-urea uptake rate, with or without acclimation to N-urea as a N-source, are shown for MCCV 054 (C) and MCCV 055 (D). Respective modeled curves (straight lines for $\mathrm{NH}_{4}{ }^{+}$, dotted lines for $\mathrm{NO}_{3}{ }^{-}$and dashed lines for $\mathrm{N}$-urea) correspond to Michaelis-Menten model and values of parameters $\left(V_{\max }, K_{\mathrm{s}}, \alpha\right)$, as well as associated $\mathrm{r}^{2}$, are listed in Table 1.
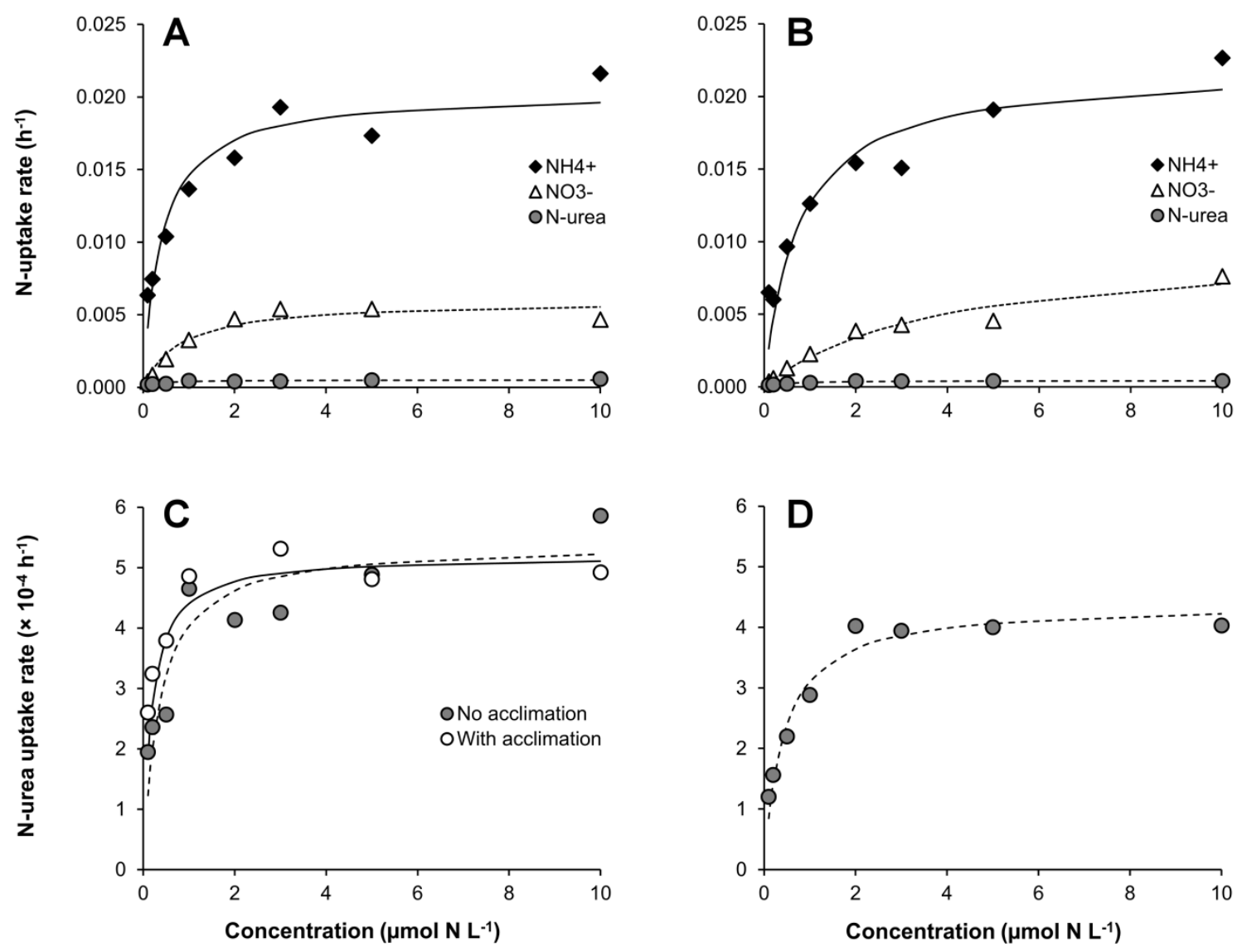
Figure 2. Variations in $\mathrm{NH}_{4}{ }^{+}$and $\mathrm{NO}_{3}{ }^{-}$uptake rates for the strain MCCV 054 of Ostreopsis cf. ovata after an addition of $10 \mu \mathrm{mol} \mathrm{N} \mathrm{L}^{-1}$ of $\mathrm{NO}_{3}{ }^{-}$and along a graded $\mathrm{NH}_{4}{ }^{+}$ concentration of 0 to $10 \mu \mathrm{mol} \mathrm{N} \mathrm{L}{ }^{-1}(A)$, or after an addition of $10 \mu \mathrm{mol} \mathrm{N} \mathrm{L}{ }^{-1}$ of $\mathrm{NH}_{4}^{+}$

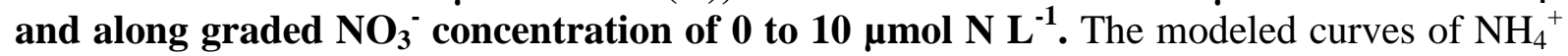
and $\mathrm{NO}_{3}{ }^{-}$uptake data correspond to solid and dotted lines, respectively. Values of parameters used for modelling these data sets are listed in Table 1 with associated $\mathrm{r}^{2}$ values.
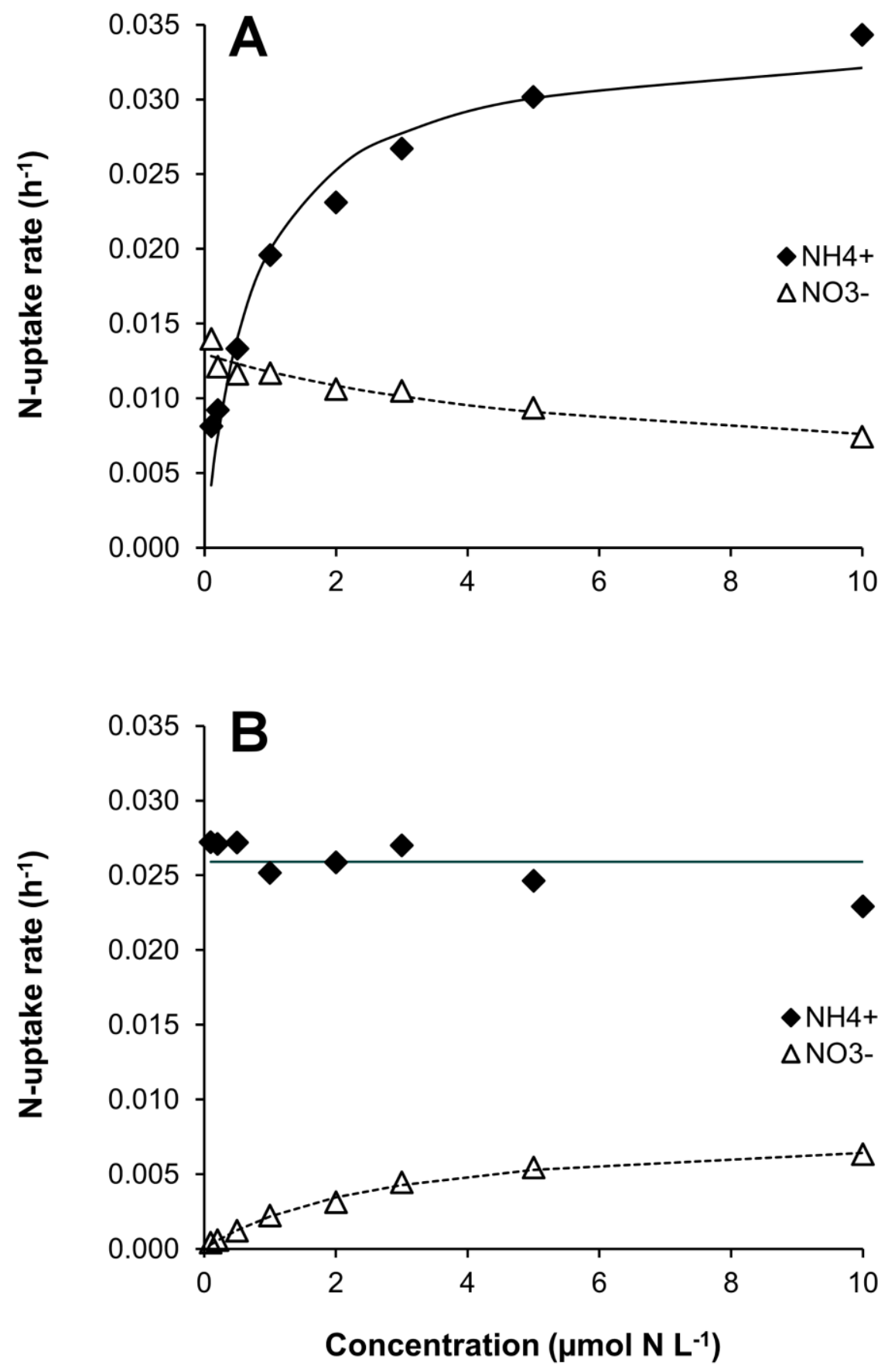
Figure 3. Variations in ${ }^{15} \mathrm{~N}$ isotopic ratios of Ostreopsis cf. ovata cells over $24 \mathrm{~h}$, after addition of $100 \mu \mathrm{mol} \mathrm{N} \mathrm{L}^{-1}$ of ${ }^{15} \mathrm{NH}_{4}{ }^{+}$or ${ }^{15} \mathrm{NO}_{3}{ }^{-}$. The dark period is indicated by the horizontal solid line. Vertical lines indicate standard deviations from three replicate cultures. Linear regressions of data sets are represented by solid lines and dashed lines for incubations with ${ }^{15} \mathrm{NH}_{4}{ }^{+}$and ${ }^{15} \mathrm{NO}_{3}{ }^{-}$, respectively. For the first light period, equations of linear regressions are $\mathrm{Y}=0.0318 \mathrm{X}-0.3111\left(\mathrm{r}^{2}=0.99\right)$ for ${ }^{15} \mathrm{NH}_{4}{ }^{+}$incubations and $\mathrm{Y}=0.0300 \mathrm{X}-0.3415\left(\mathrm{r}^{2}=\right.$ 0.99 ) for ${ }^{15} \mathrm{NO}_{3}{ }^{-}$incubations. For the dark period, equations of linear regressions are $\mathrm{Y}=0.0059$ $\mathrm{X}+0.2558\left(\mathrm{r}^{2}=0.99\right)$ for ${ }^{15} \mathrm{NH}_{4}^{+}$incubations and $\mathrm{Y}=0.0029 \mathrm{X}+0.2421\left(\mathrm{r}^{2}=0.78\right)$ for ${ }^{15} \mathrm{NO}_{3}{ }^{-}$ incubations.

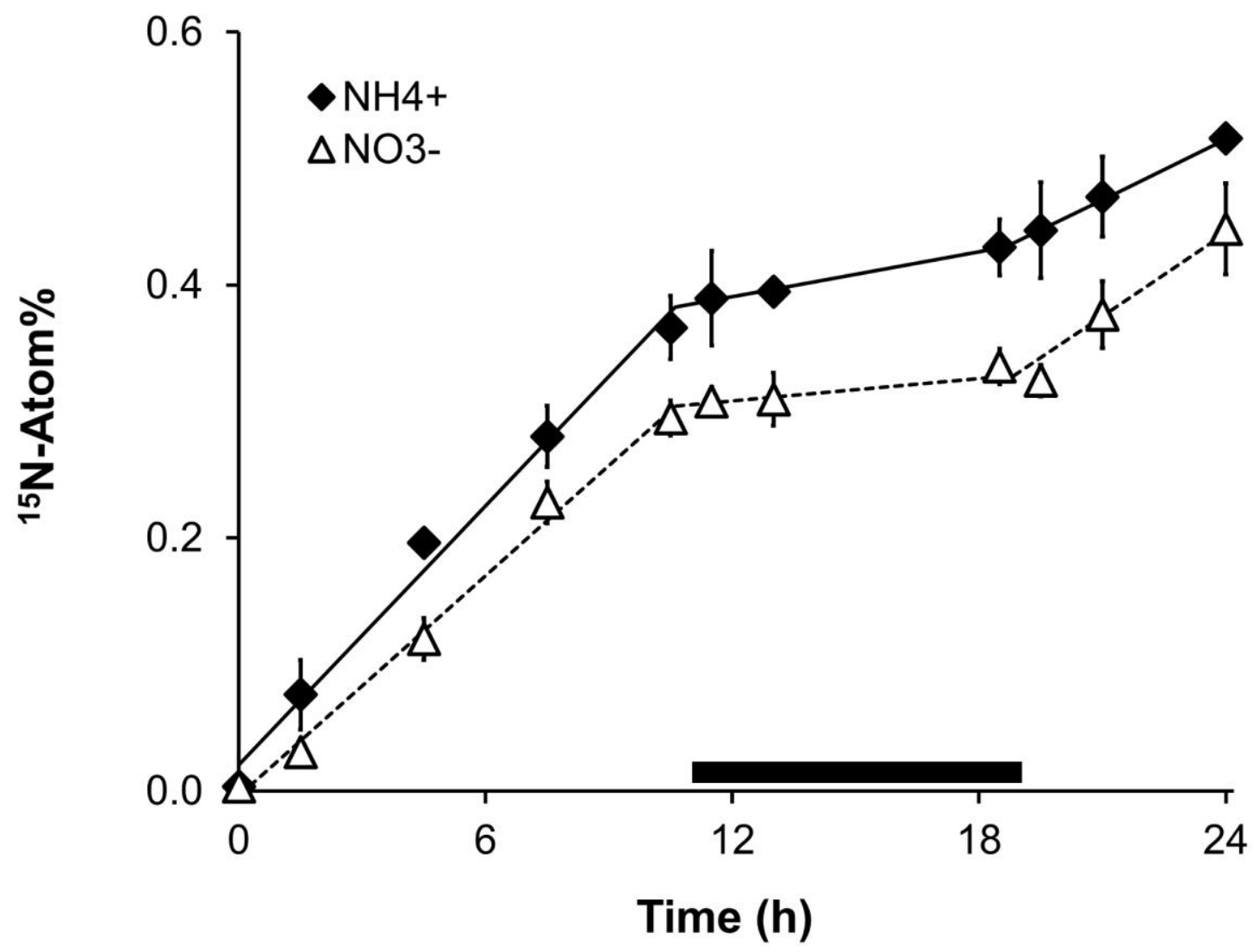


Table 1. Values of kinetic parameters $\left(V_{\max }\right.$ in $\mathrm{h}^{-1}, K_{\mathrm{s}}$ in $\mu \mathrm{mol} \mathrm{N} \mathrm{L}^{-1}, \alpha$ in $\left.\mathrm{L} \mu \mathrm{mol} \mathbf{N}^{-1} \mathbf{h}^{-1}\right)$ and inhibition parameters $\left(V_{\max -\mathrm{N}=0}\right.$ in $\mathrm{h}^{-1}, K_{\mathrm{I}}$ in $\mu \mathrm{mol} \mathrm{N} \mathrm{L} \mathbf{L}^{-1}, I_{\max }$ ) obtained for Ostreopsis cf. ovata under various culture conditions. Uptake abilities were characterized for three potential Nsources $\left(\mathrm{NH}_{4}{ }^{+}, \mathrm{NO}_{3}{ }^{-}\right.$and $\mathrm{N}$-urea), added under graded nutrient concentrations (listed in $\mu \mathrm{mol} \mathrm{N} \mathrm{L}{ }^{-1}$ ), as a unique $\mathrm{N}$-source or in combination with another one. Non-linear regressions were based on the Michaelis-Menten model or the reverse Michaelis-Menten relation.

\begin{tabular}{|c|c|c|c|c|c|c|}
\hline \multirow[t]{2}{*}{ Experiment (Strain) } & \multicolumn{2}{|c|}{${ }^{15} \mathrm{~N}$-addition } & \multicolumn{3}{|c|}{ Kinetic parameters } & \multirow[t]{2}{*}{$\mathrm{r}^{2}$} \\
\hline & $\mathrm{N}$-source & Concentration & $V_{\max }$ & $K_{\mathrm{s}}$ & $\alpha$ & \\
\hline \multirow[t]{3}{*}{ Kinetics (MCCV 054) } & $\mathrm{NH}_{4}^{+}$ & $0.1-10$ & 0.020 & 0.40 & 0.0114 & 0.92 \\
\hline & $\mathrm{NO}_{3}^{-}$ & $0.1-10$ & 0.006 & 0.80 & 0.0023 & 0.94 \\
\hline & $\mathrm{N}$-urea & $0.1-10$ & 0.0005 & 0.28 & 0.0003 & 0.82 \\
\hline Acclimation to $\mathrm{N}$-urea & $\mathrm{N}$-urea & $0.1-10$ & 0.0005 & 0.11 & 0.0004 & 0.93 \\
\hline \multirow[t]{3}{*}{ Kinetics (MCCV 055) } & $\mathrm{NH}_{4}^{+}$ & $0.1-10$ & 0.021 & 0.58 & 0.0098 & 0.89 \\
\hline & $\mathrm{NO}_{3}^{-}$ & $0.1-10$ & 0.010 & 3.73 & 0.0011 & 0.96 \\
\hline & $\mathrm{N}$-urea & $0.1-10$ & 0.0004 & 0.38 & 0.0002 & 0.96 \\
\hline \multicolumn{7}{|c|}{ Interaction $\mathrm{NH}_{4}^{+} / \mathrm{NO}_{3}^{-}(\mathrm{MCCV} 054)$} \\
\hline $\mathrm{NH}_{4}^{+}$gradient, $10 \mu \mathrm{M} \mathrm{NO}_{3}^{-}$ & $\mathrm{NH}_{4}^{+}$ & $0.1-10$ & 0.034 & 0.72 & 0.0139 & 0.95 \\
\hline \multirow[t]{3}{*}{$\mathrm{NO}_{3}^{-}$gradient, $10 \mu \mathrm{M} \mathrm{\textrm {NH } _ { 4 } ^ { + }}$} & $\mathrm{NO}_{3}^{-}$ & $0.1-10$ & 0.008 & 2.77 & 0.0012 & 0.99 \\
\hline & & & \multicolumn{3}{|c|}{ Inhibition parameters } & \\
\hline & & & $V_{\text {max-N=0 }}$ & $K_{\mathrm{I}}$ & $I_{\max }$ & \\
\hline
\end{tabular}


Table 2. Estimations of ${ }^{15} \mathrm{~N}$-uptake rates (in $\mathrm{h}^{-1}$ ) of Ostreopsis cf. ovata cells in cultures under both light and dark phases of the diel cycle. Uptake abilities were characterized for $\mathrm{NH}_{4}{ }^{+}$and $\mathrm{NO}_{3}{ }^{-}$under $\mathrm{N}$-sufficient conditions.

\begin{tabular}{llccc}
\hline Experiment (Strain) & \multicolumn{2}{l}{ Mean uptake rate } & \multirow{2}{*}{$\mathrm{r}^{2}(\mathrm{p}$ value $)$} \\
\cline { 2 - 3 } $\begin{array}{llll}\text { Diel cycle (MCCV 054) } \\
\text { First light period }\end{array}$ & $\mathrm{NH}_{4}{ }^{+}$ & 100 & & \\
& $\mathrm{NO}_{3}{ }^{-}$ & 100 & 0.032 & $0.99(\mathrm{p}<0.001)$ \\
Dark period & $\mathrm{NH}_{4}{ }^{+}$ & 100 & 0.030 & $0.99(\mathrm{p}<0.001)$ \\
& $\mathrm{NO}_{3}{ }^{-}$ & 100 & 0.006 & $0.99(\mathrm{p}=0.06)$ \\
& & & 0.003 & $0.78(\mathrm{p}=0.12)$
\end{tabular}


Table 3. Values of kinetic parameters (maximal uptake rate $V_{\max }$ in $\mathbf{h}^{-1}$ and half-saturation constant $K_{\mathrm{s}}$ in $\mu$ mol $\mathbf{N} \mathrm{L}^{-1}$ ) reported for phytoplankton species from culture experiments with $\mathbf{N}$-sufficient cells. Ranges of nutrient concentration used for kinetics are indicated in $\mu$ mol N L ${ }^{-1}$. Most of the references listed reported results obtained for actively growing N-replete cells. Some experiments were conducted from recently $\mathrm{N}$-depleted cultures at the end of the growth phase and are indicated with a footnote.

\begin{tabular}{|c|c|c|c|c|c|c|c|c|}
\hline \multirow[t]{2}{*}{ Species } & \multirow{2}{*}{$\begin{array}{l}\text { Substrate } \\
\text { concentration }\end{array}$} & \multicolumn{2}{|l|}{$\mathrm{NH}_{4}^{+}$} & \multicolumn{2}{|l|}{$\mathrm{NO}_{3}{ }^{-}$} & \multicolumn{2}{|l|}{ N-urea } & \multirow[t]{2}{*}{ Reference } \\
\hline & & $V_{\max }$ & $K_{\mathrm{s}}$ & $V_{\max }$ & $K_{\mathrm{s}}$ & $V_{\max }$ & $K_{\mathrm{s}}$ & \\
\hline \multicolumn{9}{|l|}{ Diatoms } \\
\hline Chaetoceros sp. & $0.01-40$ & & & 0.110 & 3.10 & & & Lomas and Glibert (2000) \\
\hline Pseudo-Nitzschia australis & $0.1-40$ & 0.071 & 5.37 & 0.105 & 2.82 & 0.0300 & & Cochlan et al. $(2008)^{\mathrm{ab}}$ \\
\hline Skeletonema costatum & $0.01-40$ & & & 0.100 & 0.40 & & & Lomas and Glibert (2000) \\
\hline Thalassiosira weissflogii & $0.01-40$ & & & 0.170 & 2.80 & & & Lomas and Glibert (2000) \\
\hline \multicolumn{9}{|l|}{ Dinoflagellates } \\
\hline Alexandrium catenella & $0.1-10$ & $0.002-0.026$ & $0.1-6.2$ & & & $0.0004-0.001$ & $0.6-2.3$ & Jauzein et al. $(2008 b)^{c}$ \\
\hline Alexandirum minutum & $0.1-30$ & & 0.33 & & 0.28 & & & Maguer et al. $(2007)^{\mathrm{d}}$ \\
\hline Ostreopsis cf. ovata & $0.01-10$ & 0.021 & 0.49 & 0.008 & 2.27 & 0.0005 & 0.33 & Present study \\
\hline \multirow[t]{3}{*}{ Prorocentrum minimum } & $0.01-40$ & & & 0.050 & 5.00 & & & Lomas and Glibert (2000) \\
\hline & $0.4-30$ & & 2.48 & & 5.18 & & 1.82 & Fan et al. (2003) \\
\hline & $0.2-20$ & 0.046 & 1.25 & & & 0.0004 & 0.05 & Li et al. (2011) \\
\hline Prorocentrum donghaiense & $0.1-50$ & 0.075 & 7.10 & & & 0.0400 & 0.12 & Hu et al. (2014) \\
\hline
\end{tabular}

Haptophyte 


\section{Chlorophyte}

Dunaliella tertiolecta

$$
0.01-40
$$

Raphydophyte

\section{Heterosigma akashiwo}

$0.1-12$

$$
0.028
$$$$
0.030 \quad 11.10
$$

$$
0.03011 .10
$$

Lomas and Glibert (2000)

Herndon and Cochlan $(2007)^{b}$

\section{Footnotes}

${ }^{a}$ Non-saturating kinetics were observed for N-urea uptake; the $V_{\max }$ value indicated for $\mathrm{N}$-urea uptake of $P$. asutralis in this table corresponds to the uptake rate estimated at $36 \mu \mathrm{mol} \mathrm{N} \mathrm{L}{ }^{-1}$

${ }^{\mathrm{b}}$ Experiments were conducted on recently $\mathrm{N}$-depleted cultures, in late growth phase.

${ }^{\mathrm{c}}$ Reported values correspond to incubations done just after and $3 \mathrm{~h}$ after resuspension of N-replete cells in $-\mathrm{N}$ medium.

${ }^{\mathrm{d}}$ Reported values correspond to results obtained for the higest growth rate, when $\mu / \mu \max =0.42$. 